\title{
Hetero - Atom Doped Metal-Free Carbon Nanomaterials as Potential Electrocatalyst
}

\author{
Jayeeta Chattopadhyay ${ }^{1 *}$, Tara Sankar Pathak ${ }^{2}$, Daewon Pak ${ }^{3}$
}

${ }^{1}$ Chemistry Department, Amity University Jharkhand, Ranchi 834001, Jharkhand, India

${ }^{2}$ Department of Science and Humanities, Surendra Institute of Engineering and Management, Siliguri, Darjeeling 734 009, West Bengal, India

${ }^{3}$ Department of Environmental Engineering, Seoul National University of Science and Technology, Gongneung-ro, Nowon-gu, Seoul, South Korea

Corresponding Author:

Jayeeta Chattopadhyay,

Chemistry Department, Amity University Jharkhand, Ranchi 834001, Jharkhand, India

E-mail: jayeeta08@ gmail.com

Contact: $\mathbf{+ 9 1 9 7 4 8 4 4 1 7 2 3}$ 


\begin{abstract}
:
In recent years, hetero atom incorporated specially structured metal-free carbon nanomaterials have drawn huge attention among researchers. In comparison to the un-doped carbon nanomaterials, hetero atoms like nitrogen, sulphur, boron, phosphorous etc. incorporated nanomaterials become well-accepted as potential electrocatalysts in water splitting, supercapacitors and dye-sensitized solar cells. This review emphasizes on the mostly popular synthetic strategies utilized in last two decades and their excellent performance in electrocatalytic studies.
\end{abstract}

Keywords: carbon nanomaterials; nitrogen doping; sulphur doping; co-doping; electrocatalysts 


\section{Graphical Abstract}

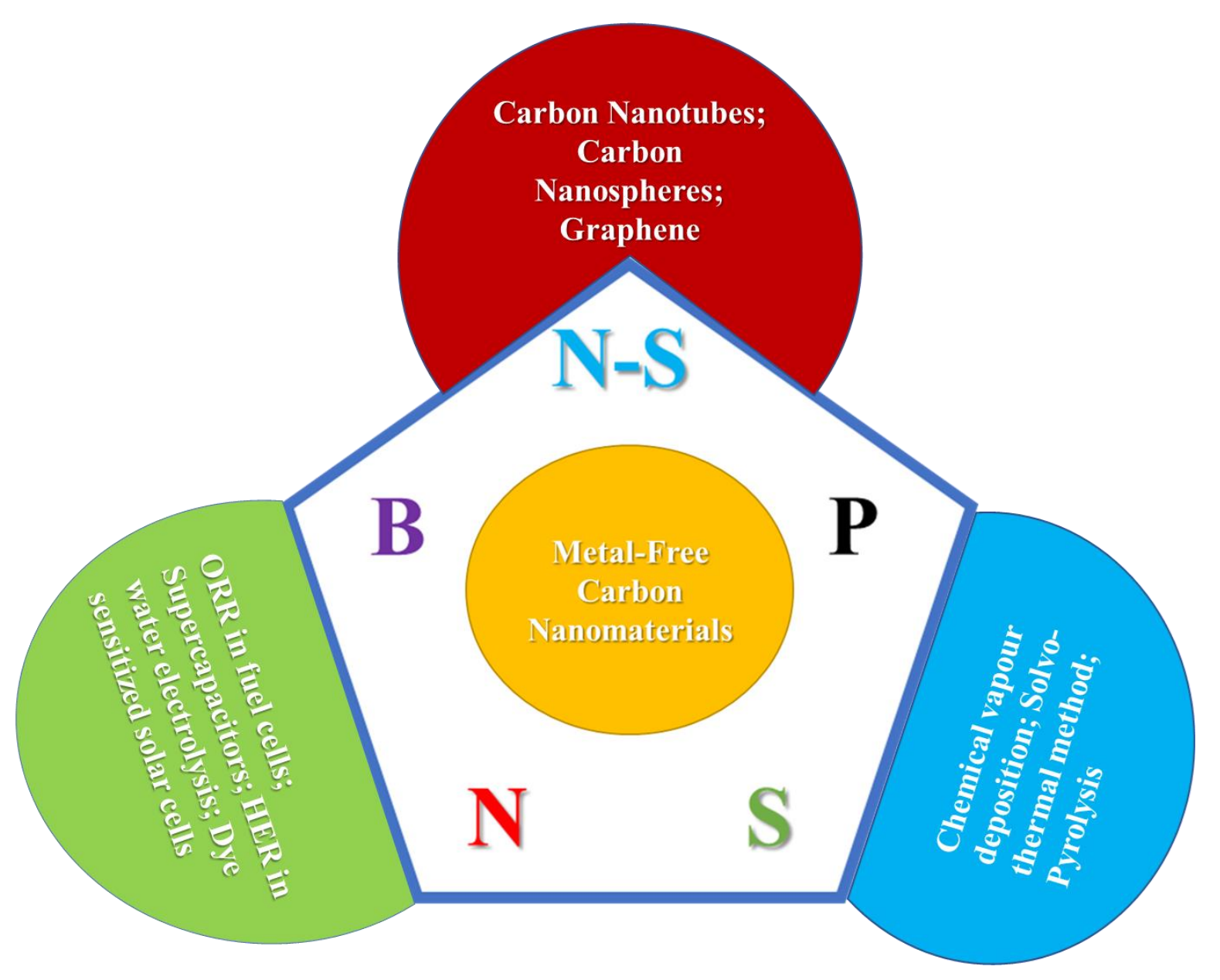




\section{Introduction:}

Energy manipulation cerates the most challenging and critical situation to the mankind in the last few decades. Energy demand and energy production are continuously establishing a disproportional relation to each other, which leads into a crucial environmental crisis globally. The over consumption of fossil fuels and excessive $\mathrm{CO}_{2}$ emission results into global warming and consequently the scientific community is being faced most challenged situation in mitigating this brutal environmental crisis. The development of potential, cost-effective technologies with no detrimental effect on environments in the purpose of green and renewable energy conversion and storage become the most serious requirement in the current scenario [1 - 3]. Moving towards this aim, fuel cells, metal-air batteries, water electrolyzer, rechargeable batteries, electrochemical capacitors constitute various technologies in respect to energy production/storage [4]. In recent years, these applications are mainly covered with various research works on oxygen reduction reaction (ORR), oxygen evolution reaction (OER), hydrogen evolution reaction (HER) and electro-reduction reaction of carbon dioxide $\left(\mathrm{CO}_{2} \mathrm{RR}\right)$ [5-8]. However, these electrochemical processes are largely restricted to apply due to their high activation energy barriers, specially in oxygen reduction reaction (ORR) kinetics performed at the cathode $[9,10]$. The much slower cathodic ORR limits the overall output performance of these useful technologies [11]. Usually, electrocatalysts play a pivotal role in reducing the activation energy barriers of ORR process. In last two decades, platinum $(\mathrm{Pt})$ based materials are continuously considered as the most potential electrocatalysts in this regard, leading to relatively higher current density and lower overpotential value [12 - 15]. Although, large scale application of these materials is restricted due to their cost ineffectiveness, easy dissolution of Pt, instability due to $\mathrm{CO}$ deactivation and fuel crossover effect. For these reasons, now-a-days, researchers are more inclined to develop electrocatalysts with following things: minimization of the Pt metal loading; alloying of Pt with other transition metals to improve 
catalytic performance $\left(\mathrm{Pt}-\mathrm{Co}, \mathrm{Pt}-\mathrm{Ni}, \mathrm{Pt}-\mathrm{Fe}, \mathrm{Pt}-\mathrm{Ru}, \mathrm{Pt}-\mathrm{Pd}, \mathrm{Pt}-\mathrm{Rh}, \mathrm{Pt}-\mathrm{TiO}_{2}\right.$ and $\mathrm{Pt}-\mathrm{Sn}$ catalysts) [16 - 18]; advanced non-precious metals and metal-oxides [19 - 23]; metalincorporated carbon materials [24 - 27]; and even metal-free catalysts [28 - 30] with remarkable electrocatalytic performance, enhanced durability, greater electrochemical stability with satisfying cost-effectiveness factor. The non-precious metal-based catalysts always show lower catalytic activity in comparison to $\mathrm{Pt} / \mathrm{C}$ and it also shows poor durability due to metal leaching during application. On the other hand, the metal-free carbon-based materials perform excellent catalytic activity during ORR. Moreover, their extraordinary chemical stability, costeffectiveness, and environmental friendliness [31 - 35]. These remarkable properties make various carbon nanostructures, viz. graphene, carbon nanotubes (CNTs) and carbon nanohorns (CNHs) huge popular in many potential application fields. The family of carbon allotropes mainly constituted by huge $\mathrm{sp}^{2}$ lattice, which is an extended $\pi$ conjugation system, results into greater thermal and electrical conductivity. Moreover, these specially structured materials act as substrate in various covalent and noncovalent modifications on their lattice structure, which results into the improvement of their inherent characteristics, and adopts the new ones [3639].

The carbon nanomaterials can be functionalized with the alteration of surface, interfacial structure and their electronic properties and their applicability reached higher level. One of the most cutting-edge functionalization technologies is chemical doping, when carbon lattice enriched with hetero atoms and their incorporation can be in the adsorptive form (in case of metal atoms), and it leaves the $\mathrm{sp}^{2}$ lattice intact. However, heteroatoms of similar radius to $\mathrm{C}$, e.g. N, O, P, S, B etc are used to bind in different configurations, where substantial effect can be seen through $\mathrm{sp}^{3}$ defects. Incorporation of heteroatoms, which is more electronegative than $\mathrm{C}$, can polarize $\mathrm{sp}^{2}$ network accordingly, therefore resulting into novel electrochemical properties. In last decade, introduction of heteroatoms into the graphitic framework structures 
got huge attention of researchers. Boron, nitrogen, phosphorus, sulphur, fluorine, chlorine, bromine, iodine, selenium, antimony and tellurium have widely been used as hetero atoms [40 - 49]. Several reviews have been published in last few years on hetero-atom doped nanomaterials applied suitably in ORR, however very few scientists have covered their overall applicability in other electrochemical reactions also. This review will cover hetero atoms doping on metal-free carbon nanomaterials as potential electrocatalysts with discussing the future challenges and perspectives in this rapidly evolving field. In this work, special attention has also been paid on their synthetic strategies and how their structural orientation could effect in their applications as electrocatalyst.

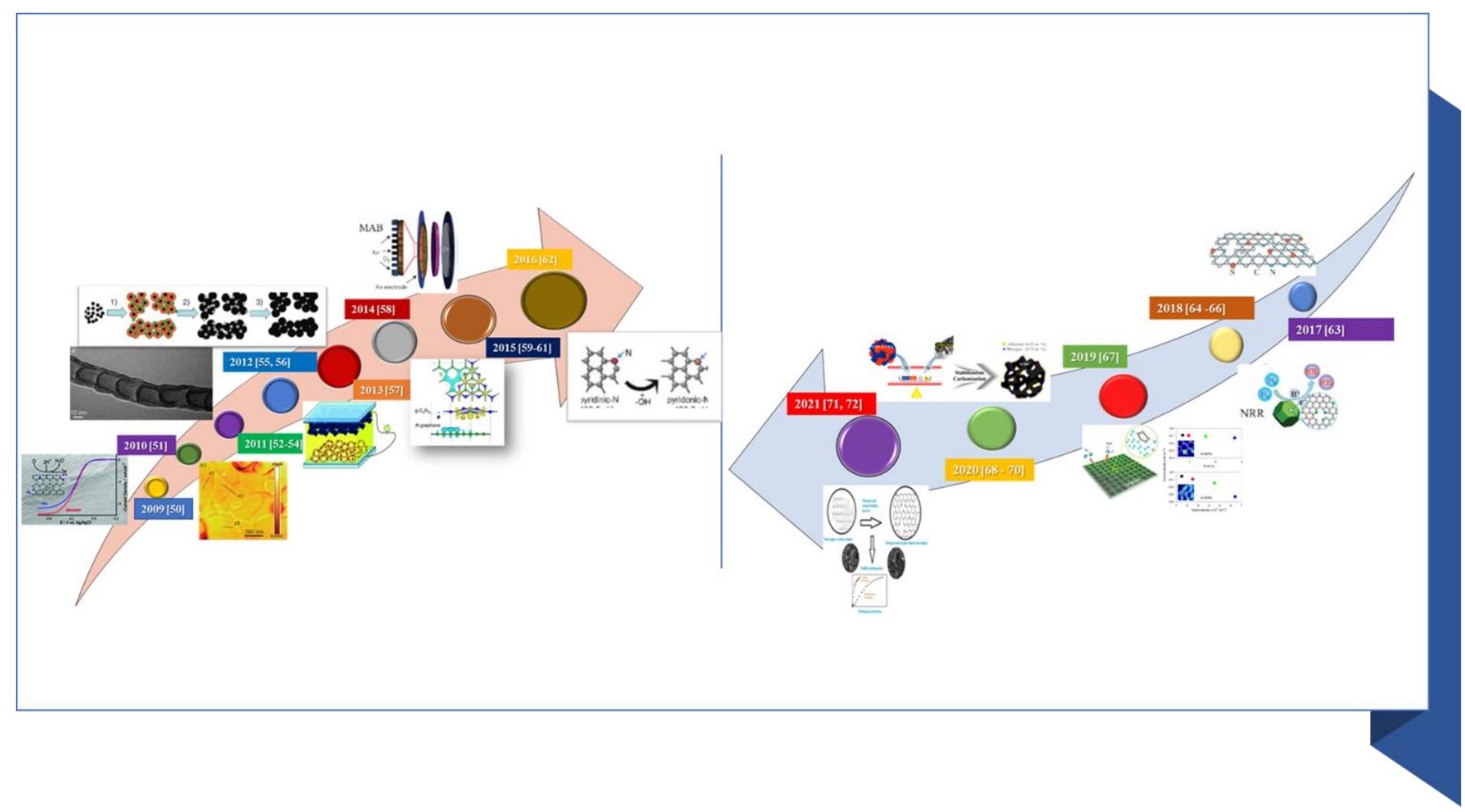

Figure 1: Developments of Hetero-atoms incorporated metal-free carbon nanomaterials in last decade 
Table 1: Hetero-atom incorporated metal-free carbon nanomaterials, synthesis and application in last decade

\begin{tabular}{|c|c|c|c|}
\hline Year & Materials & Synthesis Method & Application \\
\hline 2009 & $\begin{array}{l}\text { N-doped carbon } \\
\text { nanotubes }\end{array}$ & $\begin{array}{l}\text { Chemical vapor deposition } \\
\text { method }\end{array}$ & ORR in fuel cell application [50] \\
\hline 2010 & $\begin{array}{l}\text { N-doped } \\
\text { graphene }\end{array}$ & $\begin{array}{l}\text { Chemical vapor deposition } \\
\text { method }\end{array}$ & ORR in fuel cell application [51] \\
\hline 2011 & $\begin{array}{l}\text { N-doped carbon } \\
\text { nanotubes }\end{array}$ & $\begin{array}{l}\text { Chemical vapor deposition } \\
\text { method [52], } \\
\text { Amine Flames [53], } \\
\text { Chemical vapor deposition } \\
\text { method [54] }\end{array}$ & $\begin{array}{l}\text { ORR in microbial fuel cells [52] } \\
\text { Supercapacitors [53] }\end{array}$ \\
\hline 2012 & $\begin{array}{l}\text { (i) } \mathrm{N} \text {-doped } \\
\text { graphene foam } \\
\text { (ii) } \mathrm{N} \text {-doped } \\
\text { graphene } \\
\text { quantum dots }\end{array}$ & $\begin{array}{l}\text { (i) Post-synthesis annealing } \\
\text { in ammonia } \\
\text { (ii) Solution Chemistry }\end{array}$ & $\begin{array}{l}\text { (i) Dye sensitized solar cells [55], (ii) } \\
\text { ORR [56] }\end{array}$ \\
\hline 2013 & $\begin{array}{l}\mathrm{N} \text {-doped carbon } \\
\text { nanomaterials }\end{array}$ & Solvothermal process & Water oxidation [57] \\
\hline 2014 & $\mathrm{C}_{3} \mathrm{~N}_{4} @ \mathrm{NG}$ & $\begin{array}{l}\text { Chemical vapor deposition } \\
\text { method }\end{array}$ & HER electrocatalysts [58] \\
\hline 2015 & $\begin{array}{l}\text { (i) Nitrogen- } \\
\text { doped } \\
\text { graphene/CNT } \\
\text { composite } \\
\text { (ii) N,P-doped } \\
\text { carbon foam } \\
\text { (iii) Carbon } \\
\text { nanocages }\end{array}$ & $\begin{array}{l}\text { (i) Modified Hummers' } \\
\text { method for the GO } \\
\text { fabrication [73] } \\
\text { (ii) Pyrolysis of a } \\
\text { polyaniline aerogel } \\
\text { (iii) Hard templating } \\
\text { method }\end{array}$ & $\begin{array}{l}\text { (i) ORR in acidic fuel cell [59] } \\
\text { (ii) ORR and OER [60] } \\
\text { (iii) ORR [61] }\end{array}$ \\
\hline 2016 & $\begin{array}{l}\text { N,P-Codoped } \\
\text { Carbon Networks }\end{array}$ & Soft template and Pyrolysis & ORR and HER [62] \\
\hline 2017 & $\begin{array}{l}\text { Carbon-Based } \\
\text { Metal-Free Nano- } \\
\text { materials }\end{array}$ & Solvo thermal process & PER, ORR and HER [63] \\
\hline
\end{tabular}




\begin{tabular}{|c|c|c|c|}
\hline 2018 & $\begin{array}{l}\text { (i) N-doped } \\
\text { hierarchical } \\
\text { porous carbon } \\
\text { nanosheets } \\
\text { (ii) N-Doped } \\
\text { Porous Carbon } \\
\text { (iii) MOF-derived } \\
\text { nitrogen-doped } \\
\text { highly disordered } \\
\text { carbon }\end{array}$ & $\begin{array}{l}\text { (i) Template free method, } \\
\text { (ii) Pyrolysis } \\
\text { (iii) Solvo-thermal method }\end{array}$ & $\begin{array}{l}\text { (i) ORR [64], (ii) Electrocatalytic } \mathrm{N}_{2} \\
\text { Reduction [65], (iii) electrochemical } \\
\text { synthesis of ammonia (ESA) through } \\
\text { the nitrogen reduction reaction } \\
\text { (NRR) [66] }\end{array}$ \\
\hline 2019 & $\begin{array}{l}\text { Nitrogen doped } \\
\text { carbon-based } \\
\text { catalysts }\end{array}$ & Solvo-thermal method & Acidic oxygen reduction [67] \\
\hline 2020 & $\begin{array}{l}\text { (i)Tellurium- } \\
\text { Doped, } \\
\text { Mesoporous } \\
\text { Carbon } \\
\text { Nanomaterials (ii) } \\
\text { Nitrogen doped } \\
\text { metal-free nano- } \\
\text { materials (iii) } \\
\text { nitrogen-doped } \\
\text { metal-free nano- } \\
\text { materials }\end{array}$ & $\begin{array}{l}\text { (i)Pyrolysis (ii) Solvo- } \\
\text { thermal (iii) Solvo-thermal }\end{array}$ & $\begin{array}{l}\text { (i) Bifacial Dye-Sensitized Solar } \\
\text { Cells [68] (ii) bifunctional oxygen } \\
\text { electrocatalyst for ultrastable zinc-air } \\
\text { batteries [69] (iii) selective catalytic } \\
\text { oxidation of hydrogen sulfide [70] }\end{array}$ \\
\hline 2021 & $\begin{array}{l}\text { (i) Oxygen and } \\
\text { nitrogen-doped } \\
\text { metal-free } \\
\text { microalgae } \\
\text { carbon } \\
\text { nanoparticles (ii) } \\
\text { nitrogen-doped } \\
\text { graphene/CNT } \\
\text { composite }\end{array}$ & $\begin{array}{l}\text { (i) Potassium hydroxide } \\
\text { (KOH) activation of } \\
\text { Spirulina Platensis } \\
\text { microalgae (ii) Pyrolysis }\end{array}$ & $\begin{array}{l}\text { (i) hydrogen production from sodium } \\
\text { borohydride in methanol [71] (ii) } \\
\text { ORR in acidic fuel cell [72] }\end{array}$ \\
\hline
\end{tabular}

\section{Nitrogen Doped Metal-Free Carbon Nano-structured}

\section{Electrocatalysts:}

\subsection{Nitrogen-doped carbon nanotube electrocatalysts:}

The functionalized nano-tubes grab huge attention in the field of the reinforced and conductive plastics, sensing materials and photovoltaic materials, as scanning probe microscopy tips and many more applications. There are two broad ways to synthesize substituted N-doped CNTs: (a) in-situ process for insertion of nitrogen atom into the CNTs during the reaction only [74 - 
78]; (b) post-functionalization of CNTs with nitrogen by using various precursors and compounds like organic moieties. However, the post-functionalization method is not well investigated till now [79-81]. Arc discharge, laser ablation and plasma etching are the other synthetic strategies to develop these nano-materials [82 - 87]. Although, these methodologies require higher temperature conditions, limited type of nitrogen or carbon precursors. Moreover, rapid evaporation of precursors and application of nitrogen or ammonia atmosphere is required. In chemical vapor deposition (CVD) method, the process can be functioned at lower temperature range with and without presence of organometallic catalyst and by using wide range of carbon or nitrogen precursors. This method can produce 20-25 g of N-carbon nanotubes with application of per gram of catalyst and nitrogen atoms are embedded into the hexagonal carbon network at various ratios with 10 atoms [81]. In the literature, nitrogen incorporation has been reported with nitrogen contents of $<1$ atom $\%$ to 20 atom $\%[75,88]$. Highly oriented nanotubes with regular diameter and bond-length are termed in literature as “carpet-like" structures [90]. In this work, nitrogen is incorporated into the already synthesized CNT structure, however, this synthesis method is depicted as highly complex and tedious with multi-step techniques. The first step initiated with chemical oxidation process of tips or structural defects of CNTs, followed by coupling with other molecules, through carboxylic, carbonyl, and/or hydroxyl groups. The covalent functionalization via bond formation to the $\pi$ conjugated structure of CNT, leads to the rehybridization of $\mathrm{sp}^{2}$ bond. In this type of structure, nitrogen is attached to carbon following two different manners: (a) pyridine-type nitrogen, in which each nitrogen atom is bonded to two different carbon atoms, leading to the formation of cavities within the side-wall of the tube and (b) substitution $\mathrm{N}$, in which nitrogen atom makes bond with three $\mathrm{C}$ atoms, as presented in Figure 2. Nitrogen is containing an additional electron in its structure, in comparison to the carbon network, therefore nitrogen incorporated CNT structure usually exhibits metallic properties [90 - 92]. Nitrogen group can also enhance the 
reactivity on the graphene in comparison to the pure CNT structures, which results into the potential applications of these materials in fast responsive sensing technology, as effective field-emissions sources, and as polystyrene, epoxy composites, protein and nanoparticle immobilizers [78, 93 - 96]. The most popular covalent functionalities with application of plasma etching or by $\mathrm{HNO}_{3} / \mathrm{H}_{2} \mathrm{SO}_{4}$ treatment, to include carbonyl or carboxyl groups [97].

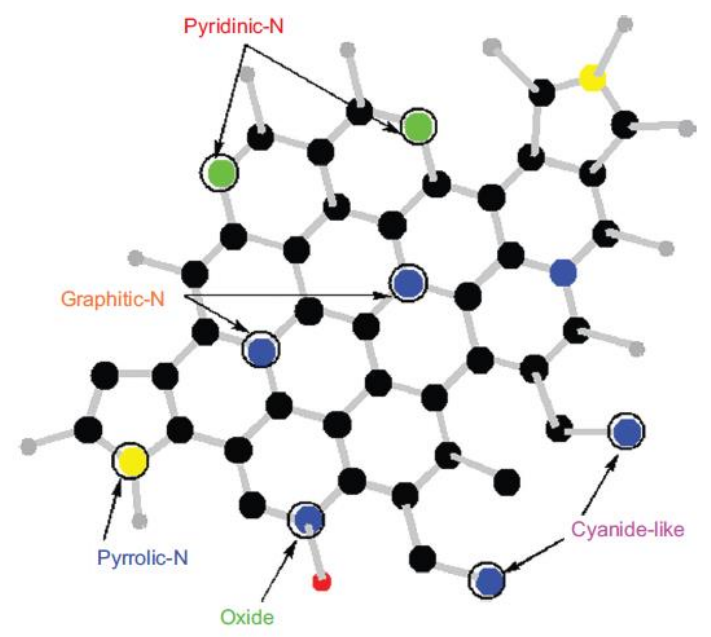

Figure 2: Nitrogen doping in the carbon nanomaterial structures [Reproduced with permission from S. Majeed et al. [89]]

The plasma etching technique is basically applicable when functionalization processes in a nitrogen atmosphere. In the next step, carboxyl groups get acylated with thionyl chloride to establish a basis for different amine compounds [98] or to combine with DNA and proteins $[99,100]$. The non-covalent functionalization is mostly conducted by the adsorption or through the wrapping the CNTs in polymer polynuclear aromatic compounds, surfactants or biomolecules by Vander Waals forces and $\pi-\pi$ interactive forces. Other synthetic approaches of CNTs include arc evaporation method of graphite $[82,101]$. The non-covalent methods are more favourable over covalent, as the chemical functionalization can be performed to the CNTs without affecting on their structures and electronic networks on the nano-tubular structures. 


\subsubsection{Chemical vapour deposition (CVD) method}

Chemical vapour deposition (CVD) is a technique to synthesize carbon nano-tubes in bulk amounts, which involve the pyrolysis of different organic molecules, viz. $\mathrm{CH}_{4}, \mathrm{C}_{6} \mathrm{H}_{6}, \mathrm{C}_{2} \mathrm{H}_{2}$ etc. in inert atmosphere over Ni, Co, Fe etc. catalysts $[102,103]$. Due to the simplicity and costeffectiveness of CVD, researchers prefer to follow this methodology during the functionalization process.

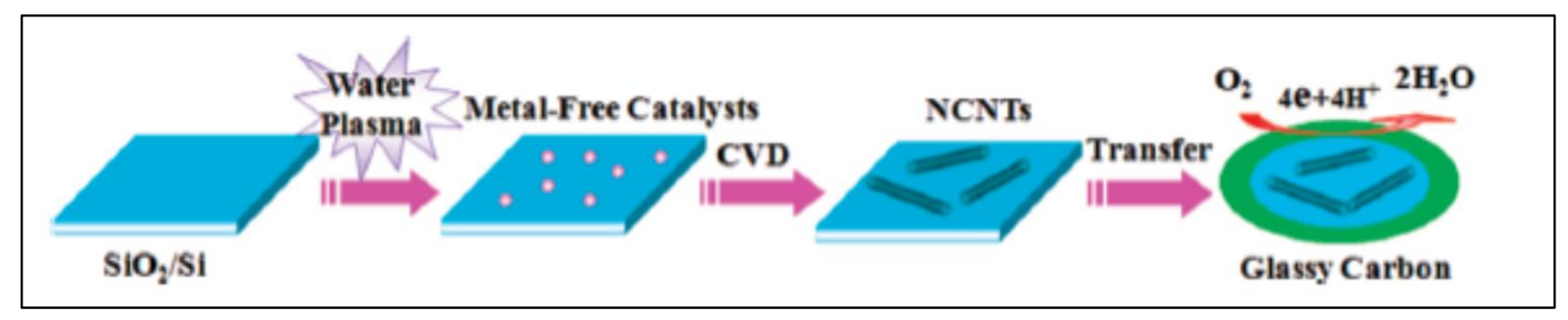

Figure 3: N-doped metal-free CNTs as ORR electrocatalysts [Reproduced with permission from Chen et al. [86]]

In 1997, Dai et al. introduced $\mathrm{H}_{2} \mathrm{O}$ plasma etching technology to generate surface patterns of polar groups with oxygen [104]. This methodology was further followed by Yu et al. [86] to develop $\mathrm{SiO}_{2}$ nanoparticles as the metal-free catalysts, in which a $\mathrm{SiO}_{2} / \mathrm{Si}$ wafer with a 30 -nmthick $\mathrm{SiO}_{2}$ coating was employed with $\mathrm{H}_{2} \mathrm{O}$ plasma etching at $30 \mathrm{~W}, 250 \mathrm{kHz}$, and 0.62 Torr for 20 mins. This plasma etched substrate further placed into a tube furnace for the synthesis of CNTs by using CVD method. Figure 3 represents the schematic diagram to represent the growth of CNTs. These materials acted as potential electrocatalysts in oxygen reduction reaction analysed in $0.5 \mathrm{M} \mathrm{H}_{2} \mathrm{SO}_{4}$ solution saturated with $\mathrm{N}_{2}$ or $\mathrm{O}_{2}$. Figure 4 shows the various electrochemical studies conducted in this work. All the electrocatalytic studies shown excellent results and long-term stability in acidic medium in comparison to undoped CNTs. The authors also claimed that, highly generic nature of the plasma etching technique, this synthetic strategy 
can be well accepted in various field, from energy applications to electronic and biomedical systems [86]. Kim et al. mentioned a similar synthesis process in $\mathrm{Ar}$ atmosphere at $800^{\circ} \mathrm{C}$ for $1 \mathrm{~h}$ duration, in which ferrocene, pyridine or ethylenediamine used as catalyst, carbon and nitrogen precursor, respectively [50]. TEM images of bamboo structured NCNTs are presented in Figure 5. These products are used as excellent electrocatalysts in ORR of fuel cell applications. The same research group reported synthesis of nitrogen doped CNTs by following a single step CVD method in which either ferrocene or iron (II) phthalocyanine as catalyst and pyridine as the carbon and nitrogen precursor, respectively. These materials have also used successfully as ORR electrocatalysts [105].
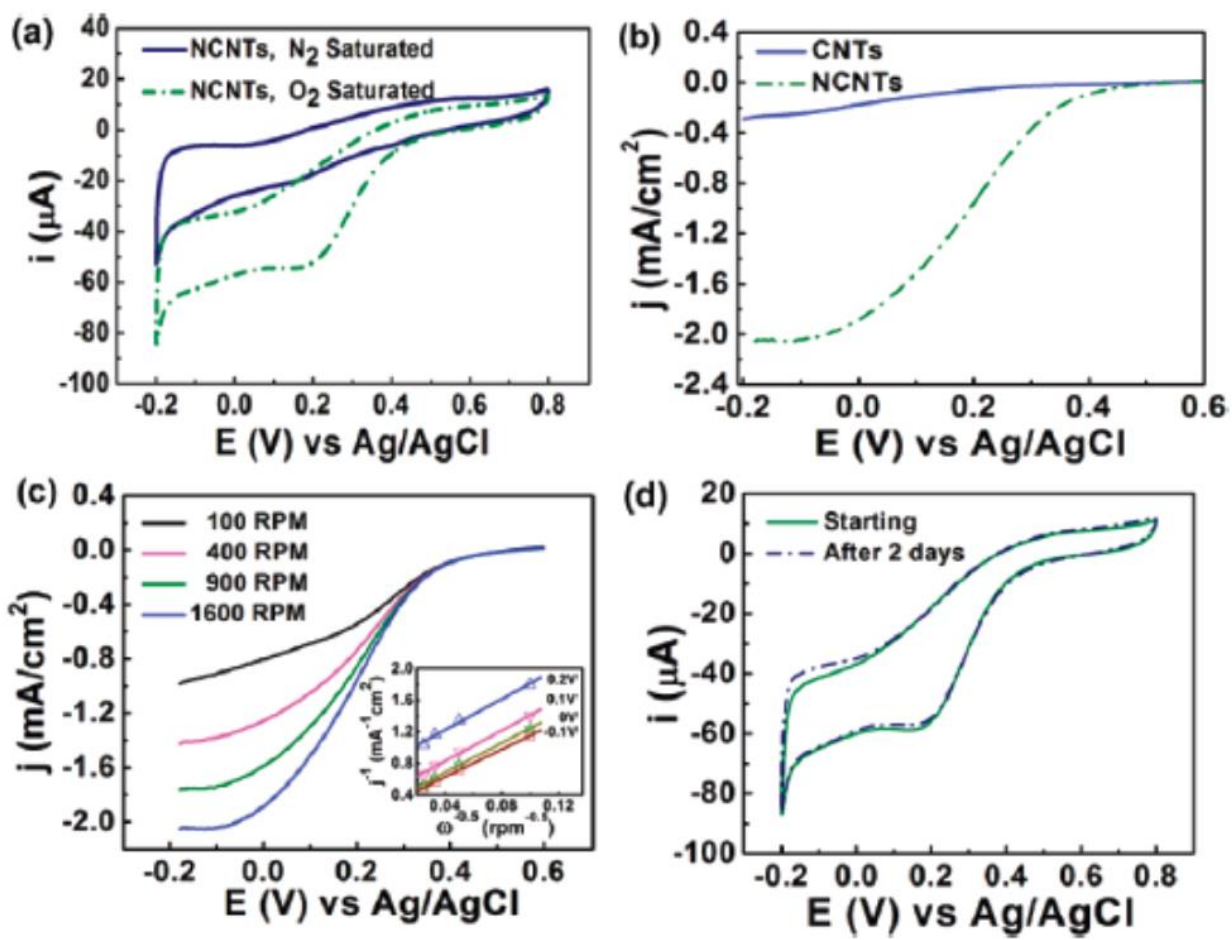

Figure 4: Electrochemical studies in ORR under acidic medium with N-doped metalfree CNTs [Reproduced with permission from Yu et al. [86]]

In 2011, Feng et al. [52] reported N-doped CNTs as effective electrocatalysts in microbial fuel cells (MFCs) with cost-effectiveness and long durability. Moreover, these materials were depicted as more effective cathodic catalysts than the commonly used platinum catalyst with 
maximum power density value of $1600 \pm 50 \mathrm{~mW} \cdot \mathrm{m}^{-2}$. These N-doped CNTs shown lower drop percentage of power densities than that with $\mathrm{Pt} / \mathrm{C}$ over 25 cycles. Another research group reported the CVD synthesis floating catalyst method of nitrogen doped carbon nanotubes using ferrocene/aniline together with toluene as added carbon source [106]. Yang et al. synthesized aligned nitrogen doped CNT bundles over $700-800^{\circ} \mathrm{C}$ by taking ammonium-exchanged zeolite$\beta$ as substrate material, ferric nitrate as catalyst and acetonitrile as carbon precursor [107]. In the same year, He et al. reported controllable synthesis of aligned $\mathrm{CNx}$ with large surface area by pyrolyzing $\mathrm{CH}_{3} \mathrm{CN} / \mathrm{Fe}\left(\mathrm{C}_{5} \mathrm{H}_{5}\right)_{2}$ on $\mathrm{SiO}_{2}$ and $\mathrm{Si}$ substrates over the temperature range of 750 $-900^{\circ} \mathrm{C}$. The specific diameters of CNTs diminished on Si substrates in comparison to a welldocumented rise with temperature on silica, as the growth process followed different mechanisms of formation of catalyst particles [108]. Kim et al. developed N-doped double walled CNTs using chemical vapor deposition in which $\mathrm{CH}_{4} / \mathrm{NH}_{3} / \mathrm{Ar}$ mixture was flowed with the rate of 50/10/500 sccm, on $\mathrm{MgO}$-supported catalyst powders at temperature of $850^{\circ} \mathrm{C}$ for 10-30 min. of duration [109], the synthesized CNTs are formed with diameter of $10-20 \mathrm{~nm}$.

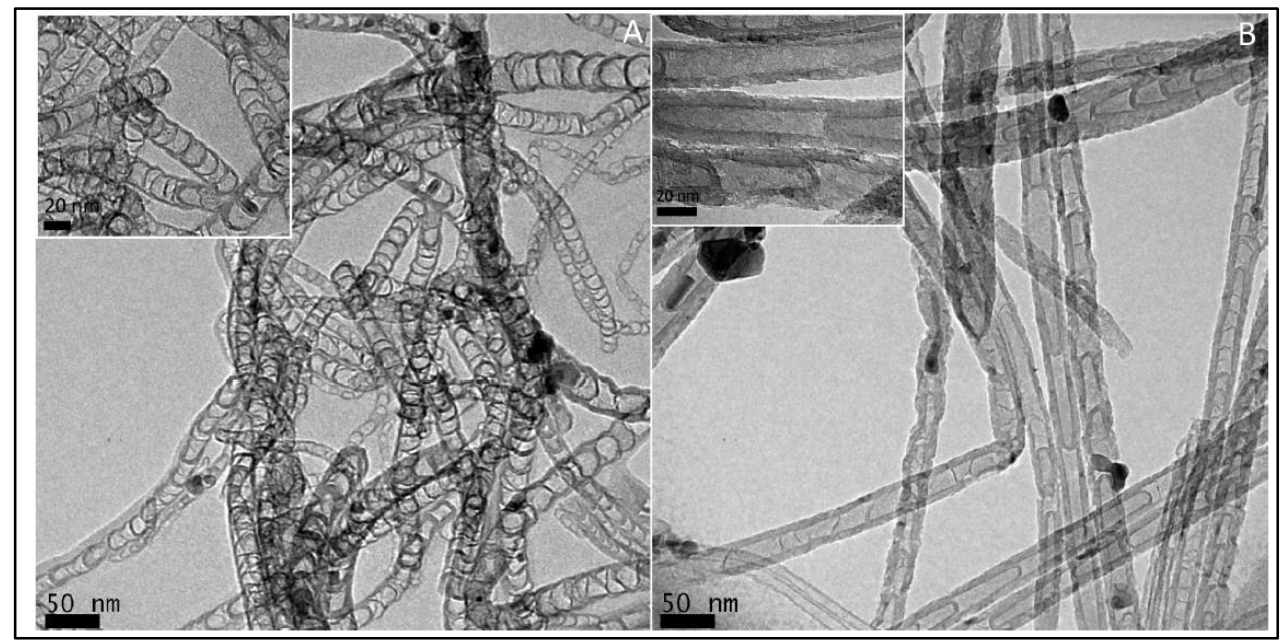

Figure 5: TEM images of Bamboo structured NCNTs [Reproduced with permission from Chen et al. [50]] 


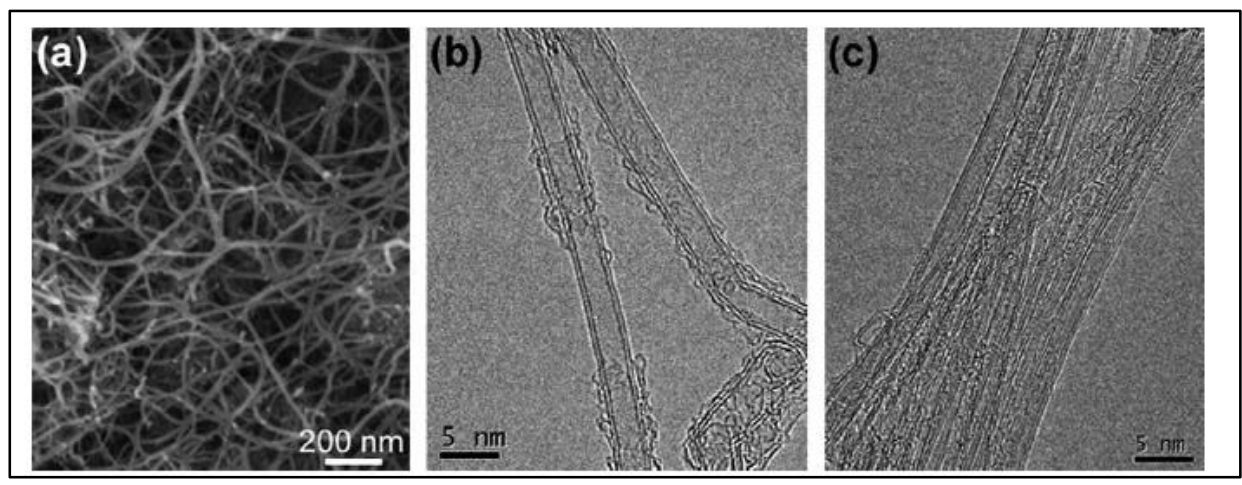

Figure 6: SEM and HRTEM images of N-doped double-walled CNTs by CVD method [Reproduced with permission from Kim et al. [109]]

In recent years, Li et al. reported a one-step CVD method to synthesize 3-dimension nitrogen doped CNT/graphene hybrid material on nickel foam [110]. In this study, nickel foam and melamine was mixed with the mass ratio of 1:5 kept in horizontal quartz tube reactor and heated in the temperature range of $600-800^{\circ} \mathrm{C}$ in hydrogen atmosphere for around $20 \mathrm{~min}$ at a flow rate of $70 \mathrm{sccm}$. In 2020, another research group mentioned a two-step synthetic strategy to develop Nitrogen-doped Carbon Nanotubes Derived from $\mathrm{g}-\mathrm{C}_{3} \mathrm{~N}_{4}$ [111]. In this case, exfoliated graphitic carbon nitride functionalized with nickel oxides and placed in the ceramic boat to keep in the tubular furnace at temperature range of $900^{\circ} \mathrm{C}$ in nitrogen atmosphere. Hydrogen was introduced further for $3 \mathrm{~h}$ in the first step, and ethylene for $10 \mathrm{~min}$ for reduction process. The synthesis of N-doped MWCNTs with straight structure was reported by Xu et al by using phthalocyanine derivatives [112] and the mixture of ethylene/hydrogen and ammonia at around $680^{\circ} \mathrm{C}$ in presence of alumina supported iron catalysts in CVD furnace [113]. The amount of nitrogen incorporated into CNT can be controlled by using different amount of nitrogen precursors $[80,114]$. The rate in which nanotubes grow during synthesis, can be enhanced with increase in its precursor significantly, resulting into the increase in intensity ratio of the $D$ to $G$ bands in Raman spectra. The inner structure of N-doped CNTs constitute regular morphological transformation from the straight and smoother walls ( 0 atom\% $\mathrm{N})$ to 1.5 atom\% 
$\mathrm{N}$ containing bamboo structured CNTs, further it changes to corrugated structures with 3.1 atom\% and above nitrogen [115]. It has been analysed by Wang et al that, during the synthesis of $\mathrm{N}$-doped CNTs, when melamine uses as $\mathrm{C} / \mathrm{N}$ initiator can incorporate 20 atom\% nitrogen. In this type of synthesis method, $\mathrm{N}$ atom present in reaction medium self-assemble with gaseous carbon without taking any assistance from metal [116]. This N-doped CNTs were utilized successfully as ORR electrocatalysts in methanol fuel cells measured in alkaline media.

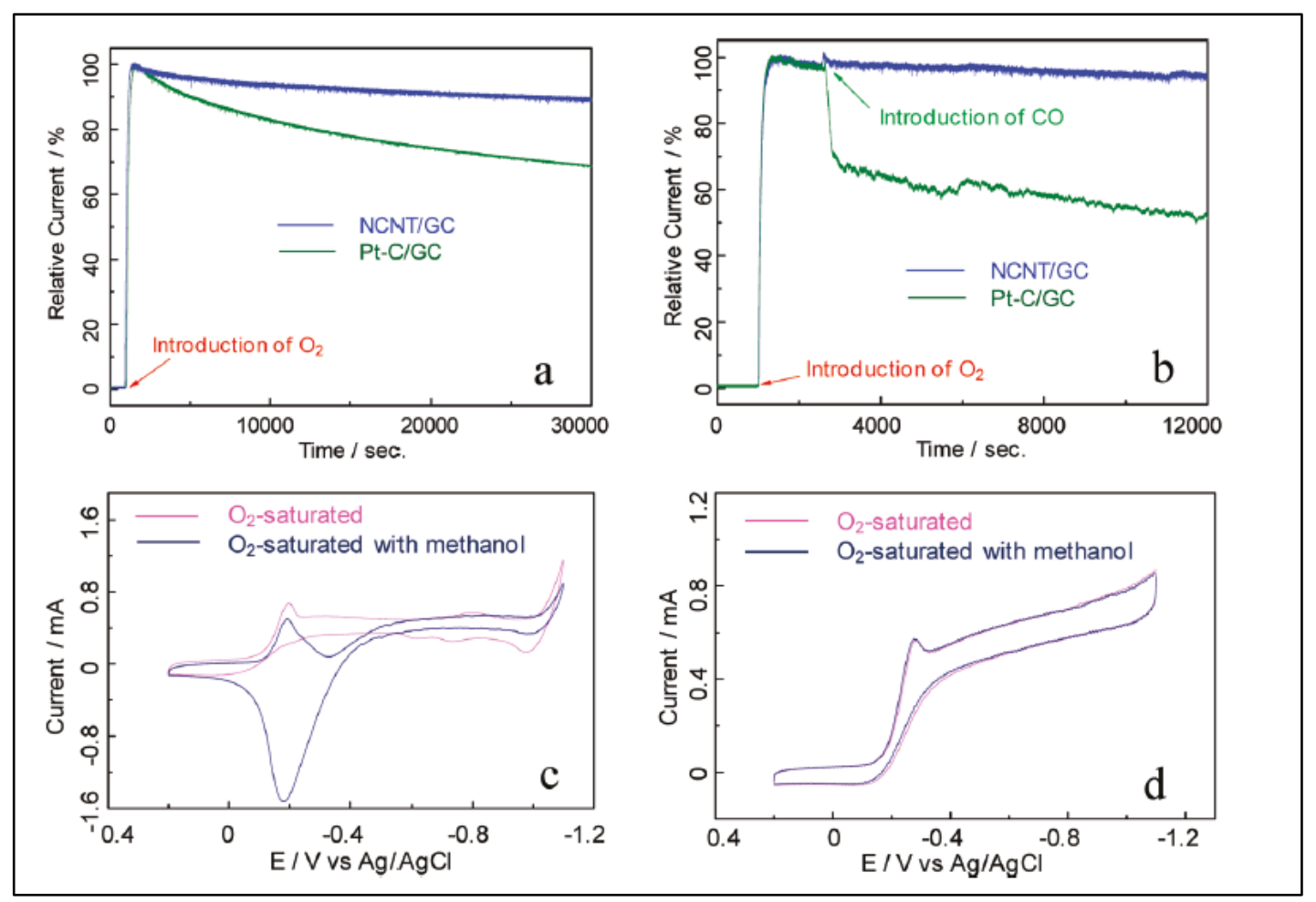

Figure 7: (a) i-t chronoamperometric studies with NCNT/GC and Pt-C/GC electrodes in oxygen saturated $0.1 \mathrm{M} \mathrm{KOH} \mathrm{(b)} \mathrm{i-t} \mathrm{responses} \mathrm{after} \mathrm{the} \mathrm{introduction} \mathrm{of} 10 \% \mathrm{CO}$. (c) Cyclic voltammograms of Pt/GC and (d) Cyclic voltammograms of NCNT/GC electrodes oxygen saturated $0.1 \mathrm{M} \mathrm{KOH,} \mathrm{with} \mathrm{and} \mathrm{without} 3 \mathrm{M}$ methanol solution [Reproduced with permission from Wang et al. [116]]

The incorporation of nitrogen atoms usually shows very strong ability to promote the selfassembled CNTs. Nitrogen can create highly active sites in carbon networks, which results into remarkable result in electrocatalytic performance comparable to traditional Pt-based materials 
as electrocatalysts. Their high activity with excellent stability and selectivity always make Ndoped CNTs better electrocatalysts in this purpose. These materials are also strong resistant to $\mathrm{CO}$ poisoning with robust structure and economically favourable. Due to doping on CNT structures, basic shape can be transformed from hollow cylinders to bamboo-shaped structure. The resultant doped materials contain plenty number of compartments whose lengths gradually decreases with variation in $\mathrm{N}$ concentration [117].

\subsubsection{Chemical and Electrochemical modification method:}

The chemical modification methods to synthesize nitrogen doped CNTs include two different approaches, viz. covalent and non-covalent. During the covalent modification, oxygen containing functional groups, viz. carboxyl and hydroxyl are formed and generated on the surface. Among the functional groups, carboxylic acid groups are chosen best options, as they can easily proceed a variety of reactions in modification process and easily can be developed using different oxidizing treatments, e.g., ozonolysis, sonication in nitric and sulfuric acid, refluxing in nitric acid etc. In the next step, carboxyl functionalized CNTs are grafted with the functional moieties by using terminal oxidation process following various mechanisms from the defect site chemistry oxidation reactions and esterification/amidation processes to the already oxidized CNTs $[118,119]$, mechano-chemical modification $[120,121]$, ionic liquids, cycloaddition reactions [122, 123], electrochemical modification reactions, diazotization [124] and radical additions [125].

The efficient and successful doping and tailoring technologies in CNTs involves the controlling of redox properties of the dopant. Nitrogen-doped CNTs excellent electrocatalytic activity comparable to Pt electrodes, can be acclaimed by the formation of additional active sites on the surface of the materials, leads to the better dispersion of the Pt particles over the N-CNT and performs better in methanol oxidation [126]. From the results, it is analysed that, doped CNTs 
as electrode materials always enhances the output power of the thermo-electrochemical cells. Doping enhances the electrochemical active surface area (ESCA) values in the CNT electrodes in proportional way. Wei et al. reported doped CNTs mixed with glutaraldehyde functionalized chitosan (GCS), which depicted an improved bio-compatibility and higher conductivity in enzyme immobilization process, due to the enhanced kinetics from the N-CNTs [127]. The electrochemical modification process was carried out through two types of coupling reactions, working under oxidative or reductive conditions. In 2002, Kooi et al. worked on anodic coupling reaction to the SWCNTs by using two different aromatic amines, viz. 4aminobenzylamine and 4-aminobenzoic acid [128]. The non-covalent functionalization process can be carried out through the porphyrin assembled on the N-doped MWCNTs, via the Fe-N coordination. Tu et al. reported this non-covalent modification by porphyrin, which led the MWNTs insoluble in water, however, performed well as catalysts and biosensors [129].

\subsection{Nitrogen-doped carbon hollow spheres:}

The carbon spheres usually refer to the spherical shaped carbon in semi-crystalline or crystalline form, constituted in solid, hollow or core-shell morphological structures. Researchers are paying huge attention on nitrogen-doped hollow spherical structures in recent years, due to their lower density, greater surface area values, better electrical conductivity with excellent structural stability. In 2012, Zhu et al. developed a hierarchical porous hollow carbon nanospheres as an oxygen reduction electrocatalyst for zinc-air batteries, which was containing active pyridinic-N and graphitic-N by using polystyrene spheres and aniline as the corresponding template and precursor [130]. Gu et al. reported N-doped porous carbon spheres with excellent porosity characteristics, which was used as potential electrocatalyst in ORR. The unique spherical structures with remarkable stability and recyclability makes these materials most promising ORR electrocatalysts [131]. Hydrothermal carbonization method was adopted to make these materials by using biomass glucose, followed by the treatment in ammonia and 
by subsequent activation treatment. Another research group reported the development of Ndoped carbon nanodots @ nanospheres, which were applied as efficient electrocatalyst in ORR, in which high electrocatalytic activity was shown with an onset potential of $-0.08 \mathrm{~V}$, greater durability and greater resistance to methanol cross-over effect; these results were comparable to commercially available $\mathrm{Pt} / \mathrm{C}$ electrocatalyst. These $\mathrm{N}$-doped carbon nanodots with sizes of 2-6 nm were successfully formed by using hydrothermal method from natural biomass (e.g., fresh grass) at temperature of $180{ }^{\circ} \mathrm{C}$ for $10 \mathrm{~h}$ duration. Further these carbon nanodots were subsequently immobilized onto functionalized microporous carbon nanospheres (MCNSs) with an average diameter of $\sim 100 \mathrm{~nm}$ and a surface area of $241 \mathrm{~m}^{2} \mathrm{~g}^{-1}$ via a simple hydrothermal process to self-assemble form a carbon-based nanocomposite $(\mathrm{N}$ CNDs@MCNSs) owing to the presence of oxygen $(\mathrm{O})$-containing surface functional groups [132]. Now-a-days, maximum number of research works are carried out on nitrogen encapsulation on metal/metal oxides/carbon nano-spheres materials potentially applied as electrodes or electrocatalysts [133 - 140]. In the current review, those works are not considered, as they are not metal-free nano-structured materials.

\subsection{Nitrogen-doped Graphene Electrocatalysts:}

Graphene is $2 \mathrm{D}$ structured with $\mathrm{sp}^{2}$ hybridized carbon with interesting physical and chemical characteristics. To achieve desired performance in electrochemical and biochemical applications, nitrogen enriched graphene materials are synthesized using wide range of methodologies [141 - 151]. In 2011, Zhang et al. developed N-doped graphene by thermal annealing of graphene oxide in presence ammonia [152]. Another research group reported facile and catalyst-free method to develop large-scale synthesis of nitrogen doped graphene with $10.1 \mathrm{wt} \%$ nitrogen content by using economically favourable industrial material melamine as nitrogen source [153]. Sheng et al. synthesized nitrogen-doped graphene using solvothermal method with the reaction between tetrachloromethane with lithium nitride under mild condition 
[154]. Figure 8 and 9 are presenting the schematic diagram to synthesize these materials and their potential electrocatalytic applications in ORR under alkaline media, respectively. Another simple way to produce $\mathrm{N}$-doped graphene nanosheets following solvothermal route by reaction between graphene oxide and urea with nitrogen content of 10.13 atom\% [155]. Temperature plays a pivotal role in solvothermal process during the doping of nitrogen in the graphene network $[152,153]$. Another research group developed pyrrolic and pyridinic type nitrogen incorporation in graphene structure at 300 and $500{ }^{\circ} \mathrm{C}$, respectively with the annealing treatment of graphene oxide in presence of glycine and $\mathrm{AgNO}_{3}$ [156]. This particular methodology produced $\mathrm{N}$-doped graphene with 13.5 atom\% of nitrogen into the materials. CVD method had also been adopted by using methane and ammonia, in which these materials were utilized as metal-free electrocatalysts in ORR applied in fuel cells [157]. Many research groups had also applied arc discharge method in $\mathrm{H}_{2}$ ad $\mathrm{He}$ atmosphere and under pyridine vapour to produce nitrogen doped graphene structure [158, 159].

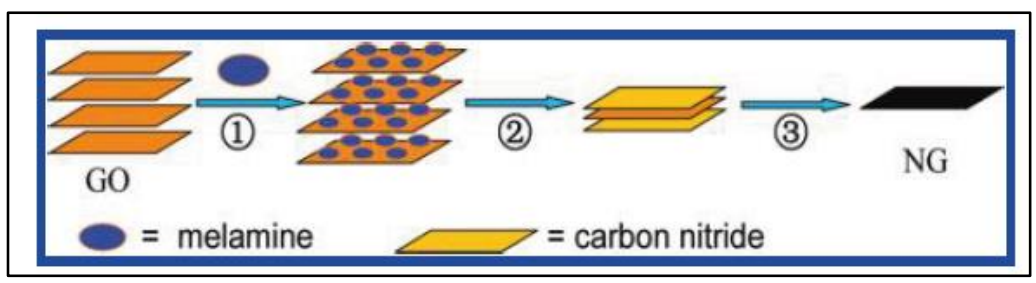

Figure 8: Schematic diagram of nitrogen doping method with melamine into GO layer [Reproduced with permission from Sheng et al. [154]]

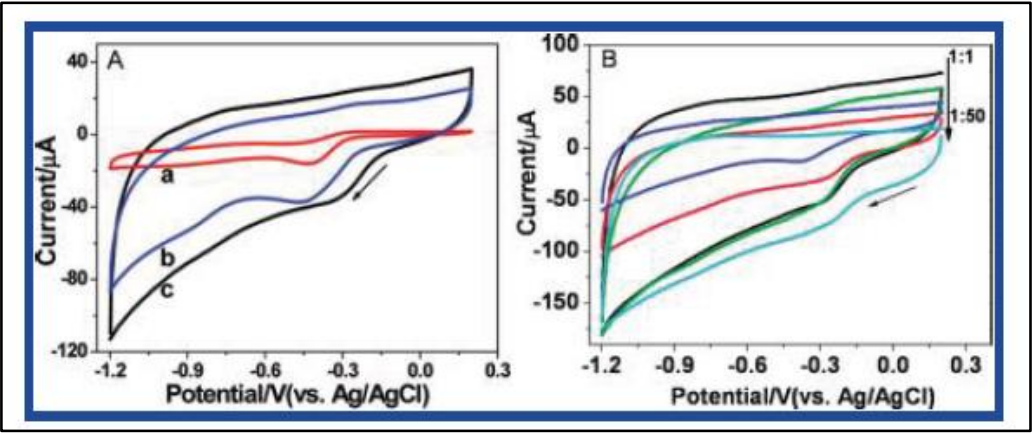


Figure 9: Cyclic voltametric results with $\mathrm{N}$-doped graphene in ORR under alkaline media [Reproduced with permission from Sheng et al. [154]]

Yang et al. reported synthesis of N-doped graphene, which successfully demonstrated as highly efficient metal-free bi-functional electrocatalysts in oxygen reduction and evolution reaction [160]. In this report, e- donating quaternary nitrogen sites were responsible for ORR, on the other hand, e- withdrawing pyridinic nitrogen acted as active sites in OER, resulting into greater transports of electrons and electrolyte [160].

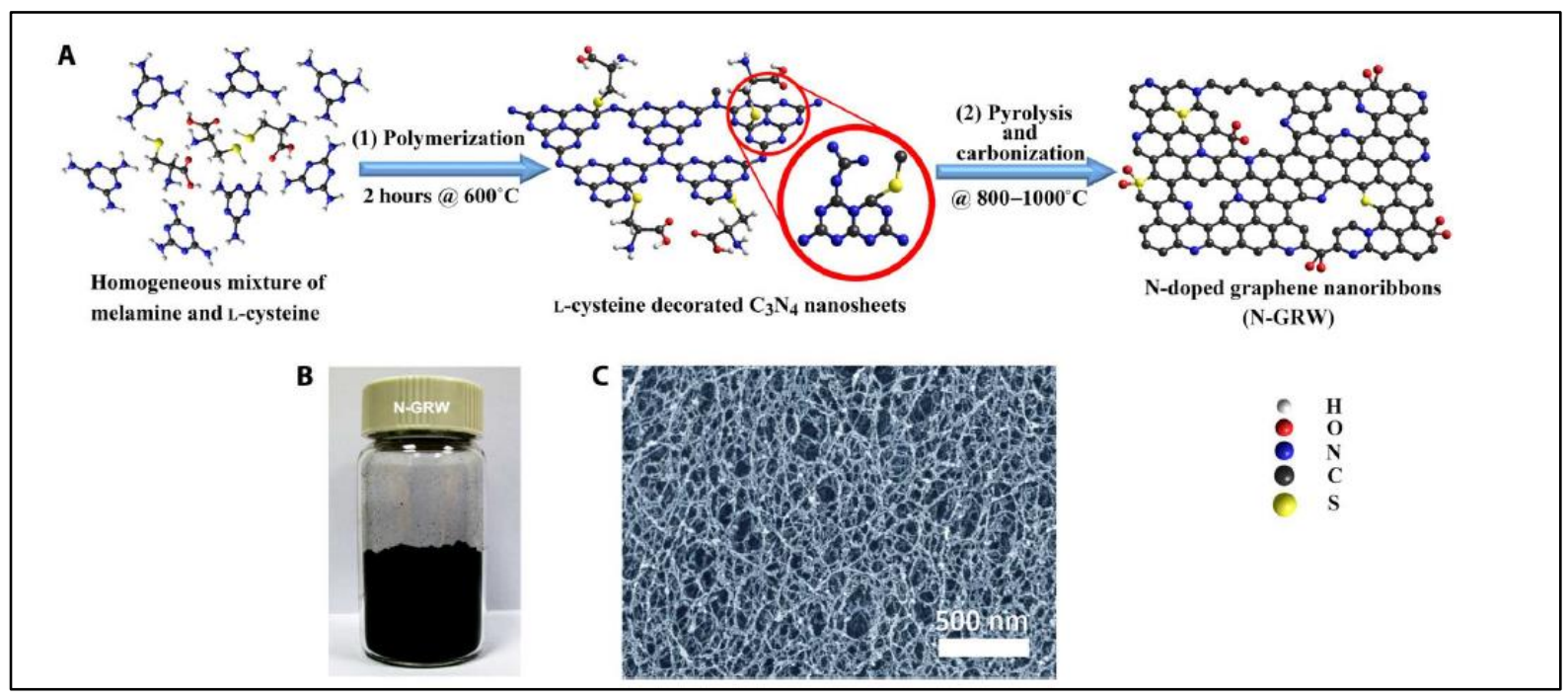

Figure 10: Synthesis of SEM image of N-doped Graphene materials [Reproduced with permission from Yang et al. [160]]

Liu et al. synthesized pyrrolic-nitrogen doped graphene which was successfully adapted as carbon free electrocatalysts in electrocatalytic reduction of carbon dioxide to formic acid and their comparative study with computational method [161]. Earlier, Ju et al. developed nitrogendoped graphene nanoplatelets as potential metal-free counter electrode materials used in organic dye-sensitized solar cells [162]. Rahsepar et al. followed a hybrid hydrothermalmicrowave process to synthesize $\mathrm{N}$-doped graphene, which exhibited remarkable electrocatalytic activity in ORR [163]. The number of catalytic sites were enhanced due to the 
incorporation of $\mathrm{N}$-atom into graphene. Maouche et al. developed nitrogen doped graphene with porous structures, which was successfully employed as ORR electrocatalyst [164]. In this work, a facile fabrication technology was carried out with graphitic carbon nitride $\left(g-\mathrm{C}_{3} \mathrm{~N}_{4}\right)$ and graphene oxide (GO) as raw materials. Another research group utilized N-doped graphene as electrocatalyst in ORR under alkaline medium and in anion exchange membrane fuel cells [165].

\section{Sulphur and Sulphur-Nitrogen Co-Doped Metal-Free Carbon Nano-materials as} Electrocatalysts:

Nitrogen doped carbon nano-materials are accepted as potential electrocatalysts in ORR by researchers due to their charge transfer induced performance using $\mathrm{N}$ contained in graphitic framework, which further induce oxygen adsorption and reduction process at comparatively lower overpotential value, which has briefly explained in previous paragraph. In recent studies, other hetero-atoms, viz. sulphur, phosphorus, boron and fluorine have also been studied to incorporate in carbon materials to promote their electrocatalytic activity in ORR as metal-free electrocatalysts in comparison to the undoped carbon nanomaterials [166 - 169]. Although, dual doping of hetero atoms has been believed as more effective electrocatalysts due to the synergistic effect between hetero atoms during ORR proceed in electrochemical performance and also in theoretical calculations. Their excellent synergistic effects induced the formation of higher numbers of catalytic sites with remarkable reactant transport effect due to their hierarchical pore structures and greater electron transfer rate, which is generated by their threedimensional continuous networked structures [170]. Li et al. mentioned that optimal doping level could be the pivotal factor to control doping density and maximum catalytic performance in resultant materials [171]. In these types of nanomaterials, the total difference in electronegativity (d) generated from nitrogen and sulphur in comparison to carbon might have generated more robust contribution in generation of innovative non-electroneutral sites in 
comparison to the mono hetero atom doped structure $\left(d_{C}=2.55, d_{N}=3.04\right.$ and $\left.d_{S}=2.58\right)$. These special types of materials were reported to be more favourable to positively charged sites in oxygen surface adsorption process, resulting into better ORR activity [172]. However, the reported works are mostly on doping of hetero atoms on CNTs and/or graphene, which can not be that much effective for their high cost and complicated synthesis methodologies.

In 2012, Wohlgemuth et al. reported the one-pot hydrothermal synthesis of sulfur and nitrogen doped carbon aerogels which were utilized as potential electrocatalysts ORR [173, 174]. In this method, two co-monomers, viz. S-(2-thienyl)-L-cysteine (TC) and 2-thienyl carboxaldehyde (TCA) were used in S incorporation using typical solvothermal method. Further, the samples were placed inside furnace under $\mathrm{N}_{2}$ atmosphere and flushed them for half an hour before heting to $900 \mathrm{oC}$ at heating rate of $10 \mathrm{~K} \mathrm{~min}^{-1}$. This secondary pyrolysis step was applied in tuning carbon aerogel conductivity and heteroatom binding states. They had also conducted comparative electrocatalytic studies of these materials with solely N-doped aerogels in ORR both in acidic and alkaline medium. They found co-doped materials as more potential candidate in electrocatalytic study, which might be affirmed due to synergistic effect between nitrogen and sulphur [173].

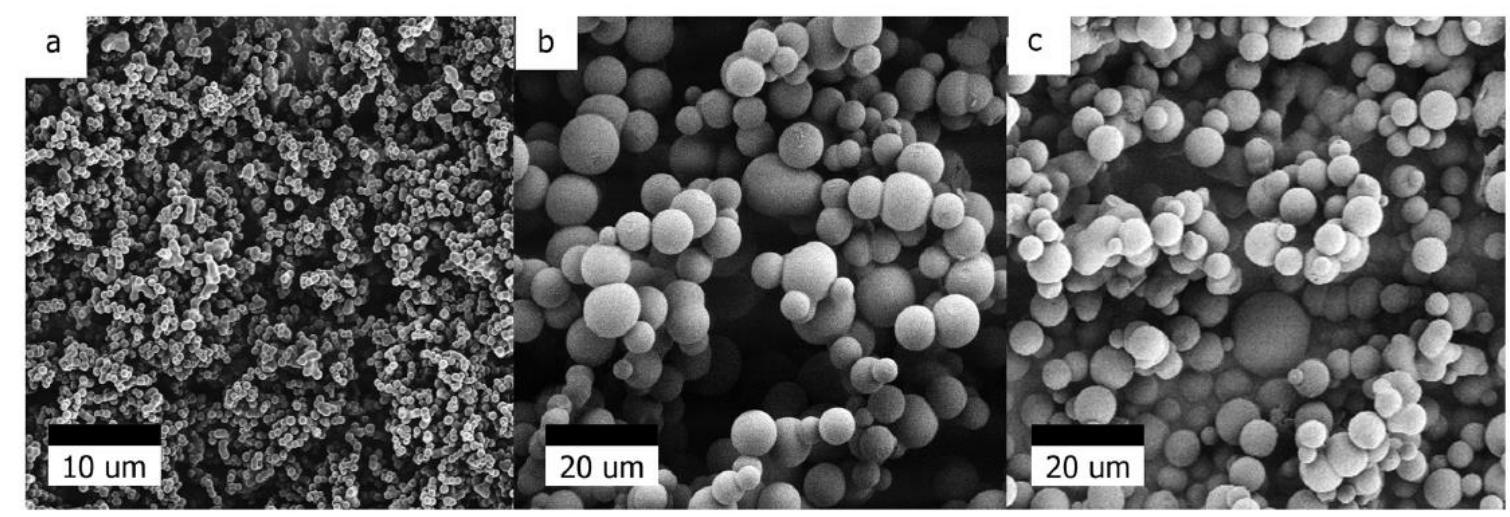

Figure 11: Scanning Electron Microscope images of products after hydrothermal carbonization method (a) pure glucose, (b) glucose with cysteine (Cys0.2) and (c) glucose 


\section{with thienyl-cysteine (TCys0.2) [Reproduced with permission from Wohlgemuth et al.} [174]]

Initially in 2002, the incorporation of sulphur into electrocatalytic performance was introduced by Wu et al. They had reported development of sulphur doped amorphous carbon as potential cathode material by heat-treatment of a mixture of polyacrylonitrile (PAN) and sulfuric acid [175]. Sulphur incorporation in the system enhanced the charge capacity value in close correlation with increase in the size of graphite crystallites, inter-layer distance and number of micro-pores. Choi et al. developed sulphur doped carbons by using pyrolysis method of bioderived amino acids, viz. alanine, cysteine, glycine, niacine and valine and utilized the materials as ORR electrocatalysts successfully in fuel cell applications. They had also synthesized nitrogen and sulphur co-doped catalyst by using cysteine, which performed best in acidic media in comparison to the commercially available Pt/C catalysts [176]. Previously, in 2006, Inamdar et al. introduced a new flame technology to synthesize spherical iron oxide nanoparticles by burning ferrocene solution using a spirit lamp [177]. The same research group synthesized carbon soot with various configuration using flame pyrolysis method [178]. Thiophene was selected as sulphur precursor material and these nano-materials were utilized as ORR electrocatalysts successfully. Park et al. reported high quality S-graphene by using lower content of oxygen - containing sulphur groups, with fluorinated graphite intercalation compounds (FGIC) derived graphene as the starting material. This synthesis process was conducted at comparatively lower temperature of $850^{\circ} \mathrm{C}$ [179]. Zhang et al. developed graphene doped N-S using cysteine as a nitrogen/sulphur source material, which were potentially utilized in ORR with better performance than Pt/C. [180]. Similar work was reported by Zhao et al. to synthesize N/S co-doped hollow carbon micro-spheres with great electrocatalytic performance in alkaline media [181]. Wang et al. used residues from bananapeel to develop porous carbons, which were co-doped with N/S [182]. These materials were 
used as ORR electrocatalysts tested in alkaline medium. As we know that, carbon can be derived from various sources by following simple methods. Among which, Cassava (Manihot esculenta) is a crop which can generate large amount of waste material as peel and pulp. It almost contributes over 700 MT waste materials in the global upstream food waste [183]. Duran et al. used cassava residues in preparation of sulphur doped metal-free electrocatalysts through a thermal functionalization with sulfuric acid which were used in ORR under alkaline media [184].

\section{Conclusions:}

The hetero-atom doped nanomaterials have drawn huge attention recently in the field of nanoscience and nanotechnology due to their synthetic methodologies, unique properties and potential electrochemical performances. In comparison to the undoped carbon nanomaterials, these specially disordered doped and co-doped materials perform remarkably well as electrocatalysts due to their larger functional surface area value and greater ratio of surface active groups to volume. These review article cover different synthetic methodologies of N, S and N/S co-doped metal-free carbon nanomaterials and discusses about their electrocatalytic activity in various electrochemical studies. The co-doping enhanced electrocatalytic activity more due to synergistic effect between them. Despite of various challenges, these specially structured nano-materials exist with many avenues and requires more progress in carbon-based nanotechnology with applications in energy field. 
References:

1. Larcher, D.; Tarascon, J.M. Towards greener and more sustainable batteries for electrical energy storage. Nat. Chem. 2015, 7, 19-29.

2. Qin, P.; Tanaka, S.; Ito, S.; Tetreault, N.; Manabe, K.; Nishino, H.; Nazeeruddin, M.K.; Gratzel, M. Inorganic hole conductor-based lead halide perovskite solar cells with $12.4 \%$ conversion efficiency. Nat. Commun. 2014, 5, 3834.

3. Xiong, D.; Li, X.; Bai, Z.; Lu, S. Recent Advances in Layered Ti3C2Tx MXene for Electrochemical Energy Storage. Small 2018, 14, 1703419.

4. Kwak, W.J.; Sharon, R.D.; Xia, C.; Kim, H.; Johnson, L.R.; Bruce, P.G.; Nazar, L.F.; Sun, Y.K.; Frimer, A.A.; Noked, M.; Freunberger, S.A.; Aurbach, D. Lithium-Oxygen Batteries and Related Systems: Potential, Status, and Future. Chem. Rev. 2020, 120, 66266683.

5. She, Z.W.; Kibsgaard, J.; Dickens, C.F.; Chorkendorff, I.; Nørskov, J.K.; Jaramillo, T.F., Combining theory and experiment in electrocatalysis: Insights into materials design. Science 2017, 355, eaad4998; 
6. Shao, M.; Chang, Q., Dodelet, J.P.; Chenitz, R.; Recent advances in electrocatalysts for oxygen reduction reaction. Chem. Rev. 2016, 116, 3594-3657;

7. Francke, R.; Schille, B.; Roemelt, M.; Homogeneously catalyzed electroreduction of carbon dioxide—-methods, mechanisms, and catalysts. Chem. Rev. 2018, 118, 4631- 4701;

8. Zhu, J.; Hu, L.; Zhao, P.; Lee, L.Y.S.; Wong, K.Y.; Recent advances in electrocatalytic hydrogen evolution using nanoparticles. Chem. Rev. 2020, 120, 851-918.

9. Suntivich, J.; Gasteiger, H.A.; Yabuuchi, N.; Nakanishi, H.; Goodenough, J.B.; ShaoHorn, Y. Design principles for oxygen-reduction activity on perovskite oxide catalysts for fuel cells and metal-air batteries. Nat. Chem. 2011, 3, 546-550.

10. Fu, S.; Zhu, C.; Song, J.; Du, D.; Lin, Y. Metal-Organic Framework-Derived NonPrecious Metal Nanocatalysts for Oxygen Reduction Reaction. Adv. Energy Mater. 2017, 7, 1700363.

11. Marcel, R. Perovskite Electrocatalysts for the Oxygen Reduction Reaction in Alkaline Media. Catalysts 2017, 7, 154. 
12. Greeley, J.; Stephens, I.E.; Bondarenko, A.S.; Johansson, T.P.; Hansen, H.A.; Jaramillo, T.F.; Rossmeisl, J.; Chorkendorff, I.; Norskov, J.K. Alloys of platinum and early transition metals as oxygen reduction electrocatalysts. Nat. Chem. 2009, 1, 552-556.

13. Cheng, N.; Banis, M.N.; Liu, J.; Riese, A.; Li, X.; Li, R.; Ye, S.; Knights, S.; Sun, X. Extremely stable platinum nanoparticles encapsulated in a zirconia nanocage by area-selective atomic layer deposition for the oxygen reduction reaction. Adv. Mater. 2015, 27, 277-281.

14. Guo, S.; Li, D.; Zhu, H.; Zhang, S.; Markovic, N.M.; Stamenkovic, V.R.; Sun, S. FePt and $\mathrm{CoPt}$ nanowires as efficient catalysts for the oxygen reduction reaction. Angew. Chem. Int. Ed. Engl. 2013, 125, 3449-3552.

15. Tan, Y.; Xu, C.; Chen, G.; Zheng, N.; Xie, Q. A graphene-platinum nanoparticlesionic liquid composite catalyst for methanol-tolerant oxygen reduction reaction. Energy Environ. Sci. 2012, 5, 6923-6927. 
16. Garcı'a, I.; Torres, M.; Crespo, M.; Rodrı'guez, C.; Estrada, E. Electrochemical study of $\mathrm{Pt}-\mathrm{Pd}, \mathrm{Pt}-\mathrm{Ru}, \mathrm{Pt}-\mathrm{Rh}$ and $\mathrm{Pt}-\mathrm{Sn} / \mathrm{C}$ in acid media for hydrogen adsorption-desorption reaction. J Alloy Comp 2007, 434:764-7.

17. Hwang, J.; Chung, J.; The morphological and surface properties and their relationship with oxygen reduction activity for platinum-iron electrocatalysts. Electrochim Acta 1993, 38:2715-23.

18. Kim, H.R.; Chattopadhyay, J.; Son, J.I.; Pak, D. Preparation of platinum-doped hollow spheres and their electrocatalytic activity in water electrolysis. Korean J. Chem. Engg. 2008, $25,775-779$.

19. Chattopadhyay, J.; Kim, H.R.; Moon, S.B.; Pak, D. Performance of tin doped titania hollow spheres as electrocatalysts for hydrogen and oxygen production in water electrolysis. Int. J. Hydrogen Energy 2008; 33: 3270 - 80.

20. Nouseen, S.; Singh, P.; Lavate, S.; Chattopadhyay, J.; Kuchkaev, A.M.; Yakhvarov, D.G.; Rohit Srivastava, R. Transition metal based ternary hierarchical metal sulphide microspheres as electrocatalyst for splitting of water into hydrogen and oxygen fuel. Catalysis. Today 2021; https://doi.org/10.1016/j.cattod.2021.05.019 . 
21. Srivastava, R.; Chattopadhyay, J.; Patel, R.; Agarwal, S.; Nouseen, S.; Kumar, S.; Karmakar, S. Highly efficient ternary hierarchical NiV2S4 nanosphere as hydrogen evolving electrocatalyst. Int. J. Hydrogen Energy 2020, 45: 21308-21318.

22. Chattopadhyay, J; Srivastava, R.; Srivastava, P.K. Ni-doped TiO2 hollow spheres as electrocatalysts in water electrolysis for hydrogen and oxygen production. J. App. Elec. 2013, 43, 279-287.

23. Chattopadhyay, J; Srivastava, R.; Srivastava, P.K. Electrochemical performance of $\mathrm{Ni} / \mathrm{TiO} 2$ hollow sphere in proton exchange membrane water electrolyzers system. Korean J. Chem. Engg. 2013, 30,1571-1577.

24. Chattopadhyay, J.; Pathak, T.S.; Srivastava, R.; Singh, A.C. Ni Nano-particle Encapsulated in Hollow Carbon Sphere Electrocatalyst in Polymer Electrolyte Membrane Water Electrolyzer. Electrochimica Acta 2015, 167, 429-438.

25. Chattopadhyay, J; Srivastava, R.; Srivastava, P.K. Preparation of Tin-doped Carbon Hollow Spheres and Their Electrocatalytic activity in Water Electrolysis. Int. J. Electrochem. Sci. $2013,8,3740-3754$. 
26. Chattopadhyay, J.; Singh, S.; Srivastava, R. Enhanced electrocatalytic performance of Mo-Ni encapsulated in onion-like carbon nano-capsules. J. Appl. Electrochemistry 2020, 50, $207-216$.

27. Kumar, S.; Srivastava, R.; Chattopadhyay, J. MxOy/M/graphene coated multi-shelled nano-sphere as Bi-functional electrocatalysts for hydrogen and oxygen evolution. Int. J. Hydrogen Energy 2021, 46, 341-356.

28. Xiong, D.; Li, X.; Fan, L.; Bai, Z. Three-Dimensional Heteroatom-Doped Nanocarbon for Metal-Free Oxygen Reduction Electrocatalysis: A Review. Catalysts 2018, 8, 301.

29. Sideri, I.K.; Tagmatarchis, N. Noble-Metal-Free Doped Carbon Nanomaterial Electrocatalysts. Chem. Eur. J. 2020, 10.1002/chem.202003613.

30. Liu, S.; Yang, H.; Su, X.; Ding, J.; Mao, Q.; Huang, Y.; Zhang, T.; Liu, B. Rational design of carbon-based metal-free catalysts for electrochemical carbon dioxide reduction: A review. Journal of Energy Chemistry 2019, 36, 95-105.

31. Wang, Y.-J.; Fang, B.; Zhang, D.; Li, A.; Wilkinson, D.P.; Ignaszak, A.; Zhang, L.; Zhang, J. A Review of Carbon-Composited Materials as Air-Electrode Bifunctional Electrocatalysts for Metal-Air Batteries. Electrochem. Energy Rev. 2018, 1, 1-34. 
32. Liu, X.; Dai, L. Carbon-based metal-free catalysts. Nat. Rev. Mater. 2016, 1, 16064.

33. Li, Q.; Zhang, S.; Dai, L.; Li, L.S. Nitrogen-doped colloidal graphene quantum dots and their size-dependent electrocatalytic activity for the oxygen reduction reaction. J. Am. Chem. Soc. 2012, 134, 18932-18935.

34. 26. Lin, Z.;Waller, G.; Liu, Y.; Liu, M.;Wong, C.-P. Facile Synthesis of NitrogenDoped Graphene via Pyrolysis of Graphene Oxide and Urea, and its Electrocatalytic Activity toward the Oxygen-Reduction Reaction. Adv. Energy Mater. 2012, 2, 884-888.

35. Wang, H.; Jia, J.; Song, P.; Wang, Q.; Li, D.; Mind, S.; Qiana, C.; Wang, L.; Li, Y.F.; Mae, C.; Wu, T.; Yuan, J.; Antonietti, M.; Ozin, G.A. Efficient Electrocatalytic Reduction of CO2 by Nitrogen-Doped Nanoporous Carbon/Carbon Nanotube Membranes: A Step Towards the Electrochemical CO2 Refinery. Angewandte Chemie. 2017, 56, 7847-7852.

36. Stergiou, A.; Cantón-Vitoria, R.; Psarrou, M.N.; Economopoulos, S.P.; Tagmatarchis, N.; Functionalized Graphene and Targeted Applications - Highlighting the Road from Chemistry to Applications. Prog. Mater. Sci. 2020,114, 100683.

37. Karousis, N.; Tagmatarchis, N.; Tasis, D.; Current Progress on the Chemical Modification of Carbon Nanotubes. Chem. Rev. 2010, 110, 5366-5397. 
38. Tasis, D.; Tagmatarchis, N.; Bianco, A.; Prato, M.; Chemistry of Carbon Nanotubes. Chem. Rev. 2006, 106, 1105-1136.

39. Karousis, N.; Suarez-Martinez, I.; Ewels, C.P.; Tagmatarchis, N.; Structure, Properties, Functionalization, and Applications of Carbon Nanohorns. Chem. Rev. 2016, 116, 4850-4883.

40. Jana, D.; Sun, C.L.; Chen, L.C.; Chen, K.H.; Effect of chemical doping of boron and nitrogen on the electronic, optical, and electrochemical properties of carbon nanotubes. Prog. Mater Sci. 2013, 58, 565-635.

41. Sumpter, B.G.; Huang, J.; Meunier, V.; Romo-Herrera, J.M.; Cruz-Silva, E.; Terrones, H.; Terrones, M.; A theoretical and experimental study on manipulating the structure and properties of carbon nanotubes using substitutional dopants. Int. J. Quantum Chem 2009, 109, 97-118.

42. Ekimov, E.A.; Sidorov, V.A.; Bauer, E.D.; Mel'nik, N.N.; Curro, N.J.; Thompson, J.D.; Stishov, S.M.; Superconductivity in diamond. Nature 2004, 428, 542-545.

43. Czerw, R.; Terrones, M.; Charlier, J.C.; Blase, X.; Foley, B.; Kamalakaran, R.; Grobert, N.; Terrones, H.; Tekleab, D.; Ajayan, P.M.; Blau, W.; Rühle, M.; Carroll, D.L.; Identification of Electron Donor States in N-Doped Carbon Nanotubes. Nano Lett. 2001, 1, 457-460. 
44. Cruz-Silva, E.; Cullen, D.A.; Gu, L.; Romo-Herrera, J.M.; Muñoz- Sandoval, E.; López-Urías, F.; Sumpter, B.G.; Meunier, V.; Charlier, J.C.; Smith, D.J.; Terrones, H.; Terrones, M.; Heterodoped Nanotubes: Theory, Synthesis, and Characterization of Phosphorus-Nitrogen Doped Multiwalled Carbon Nanotubes. ACS Nano 2008, 2, 441-448.

45. Fan, Q.; Noh, H.J.; Wei, Z.; Zhang, J.; Lian, X.; Ma, J.; Jung, S.M.; Jeon, I.Y.; Xu, J.; Baek, J.B.; Edge-thionic acid-functionalized graphene nanoplatelets as anode materials for high-rate lithium ion batteries. Nano Energy 2019, 62, 419-425.

46. Jeon, I.Y.; Ju, M.J.; Xu, J.; Choi, H.J.; Seo, J.M.; Kim, M.J.; Choi, I.T.; Kim, H.M.; Kim, J.C.; Lee, J.J.; Liu, H.K.; Kim, H.K.; Dou, S.; Dai, L.; Baek, J.B.; Edge-Fluorinated Graphene Nanoplatelets as High Performance Electrodes for Dye-Sensitized Solar Cells and Lithium Ion Batteries. Adv. Funct. Mater. 2015, 25, 1170-1179.

47. Jeon, I.Y.; Choi, H.J.; Choi, M.; Seo, J.M.; Jung, S.M.; Kim, M.J.; Zhang, S.; Zhang, L.; Xia, Z.; Dai, L.; Park, N.; Baek, J.B.; Direct nitrogen fixation at the edges of graphene nanoplatelets as efficient electrocatalysts for energy conversion. Sci. Rep. 2013, 3, article no. 2260.

48. Ju, M.J.; Jeon, I.Y.; Kim, H.M.; Choi, J.I.; Jung, S.M.; Seo, J.M.; Choi, I.T.; Kang, S.H.; Kim, H.S.; Noh, M.J.; Lee, J.J.; Jeong, H.Y.; Kim, H.K.; Kim, Y.H.; Baek, J.B.; Edge- 
selenated graphene nanoplatelets as durable metal-free catalysts for iodine reduction reaction in dye-sensitized solar cells. Sci. Adv. 2016, 2, e1501459.

49. Jeon, I.Y.; Kim, H.M.; Kweon, D.H.; Jung, S.M.; Seo, J.M.; Shin, S.H.; Choi, I.T.; Eom, Y.K.; Kang, S.H.; Kim, H.K.; Ju, M.J.; J.-B. Baek, J.B.; Metalloid tellurium-doped graphene nanoplatelets as ultimately stable electrocatalysts for cobalt reduction reaction in dyesensitized solar cells. Nano Energy 2016, 30, 867-876.

50. Chen, Z.; Higgins, D.; Tao, H.; Hsu, R.S.; Chen, Z.; Highly Active Nitrogen-Doped Carbon Nanotubes for Oxygen Reduction Reaction in Fuel Cell Applications. J. Phys. Chem. C 2009, 113, 21008-21013.

51. Qu, L.; Liu, Y.; Baek, J.B.; Dai, L.; Nitrogen-Doped Graphene as Efficient Metal-Free Electrocatalyst for Oxygen Reduction in Fuel Cells. ACS Nano 2010, 4, 1321-1326.

52. Feng, L.; Yan, Y.; Chen, Y.; Wang, L.; Nitrogen-doped carbon nanotubes as efficient and durable metal-free cathodic catalysts for oxygen reduction in microbial fuel cells. Energy Environ. Sci., 2011, 4, 1892-1899.

53. Lingmin Liao, L.; Pan, C.; Enhanced Electrochemical Capacitance of Nitrogen-Doped Carbon Nanotubes Synthesized from Amine Flames. Soft Nanoscience Letters, 2011, 1, 16-23. 
54. O'Byrne, J.P.; Li, Z.; Jones, S.L.T.; Fleming, P.G.; Larsson, J.A.; Morris, M.A.; Holmes, J.D.; Nitrogen-doped carbon nanotubes: growth, mechanism and structure. Chem Phys Chem. 2011, 18, 2995-3001.

55. Xue, Y.; Liu, J.; Chen, H.; Nitrogen-doped graphene foams as metal-free counter electrodes in high-performance dye sensitized solar cells. Angew Chem, Int Ed. 2012, 51, 12124-12127.

56. Li, Q.; Zhang, S.; Dai, L.; Li, L.; Nitrogen-doped colloidal graphene quantum dots and their size-dependent electrocatalytic activity for the oxygen reduction reaction. J. Am.

Chem. Soc. 2012, 134,18932-18935.

57. Zhao, Y.; Nakamura, R.; Kamiya, K.; Nakanishi, S.; Hashimoto, K.; Nitrogen-doped carbon nanomaterials as non-metal electrocatalysts for water oxidation. Nat Commun. 2013, 4, 2390.

58. Zheng, Y.; Jiao, Y.; Zhu, Y., Hydrogen evolution by a metal free electrocatalyst. Nat. Commun. 2014, 5, 3783.

59. Shui, J.; Wang, M.; Du, F.; Dai, L.; N-doped carbon nanomaterials are durable catalysts for oxygen reduction reaction in acidic fuel cells. Sci Adv. 2015, 1, e1400129. 
60. Zhang, J.; Zhao, Z.; Xia, Z.; Dai, L. A metal-free bifunctional electrocatalyst for oxygen reduction and oxygen evolution reactions. Nat Nanotechnol. 2015,10, 444-452.

61. Jiang, Y.; Yang, L.; Sun, T.; Significant contribution of intrinsic carbon defects to oxygen reduction activity. ACS Catal. 2015, 5, 6707-6712.

62. Zhang J, Qu L, Shi G, Liu J, Chen J, Dai L. N,P-codoped carbon networks as efficient metal-free bifunctional catalysts for oxygen reduction and hydrogen evolution reactions. Angew Chem, Int Ed. 2016, 55, 2230-2234.

63. Hu, C.; Dai, L.; Multifunctional carbon-based metal-free electrocatalysts for simultaneous oxygen reduction, oxygen evolution, and hydrogen evolution. Adv Mater. 2017, $29,1604942$.

64. Liu, L.; Zeng, G.; Chen, J.; Bi, L.; Dai, L.; Wen, Z.; N-doped porous carbon nanosheets as pH-universal ORR electrocatalyst in various fuel cell devices. Nano Energy. 2018, 49, 393402.

65. Liu, Y.; Su, Y.; Quan, X.; Fan, X.; Chen, S.; Yu, H.; Zhao, H.; Zhang, Y.; Zhao, J.; Facile ammonia synthesis from electrocatalytic N2 reduction under ambient conditions on N doped porous carbon. ACS Catal. 2018, 8, 1186-1191. 
66. Mukherjee, S.; Cullen, D.A.; Karakalos, S.; Liu, K.; Zhang, H.; Zhao, S.; Xu, H.; Karren, L.M.; Wang, G.; Wu, G.; Metal-organic framework-derived nitrogen-doped highly disordered carbon for electrochemical ammonia synthesis using $\mathrm{N} 2$ and $\mathrm{H} 2 \mathrm{O}$ in alkaline electrolytes. Nano Energy. 2018, 48, 217-226.

67. Jia, Y.; Zhang, L.; Zhuang, L.; Liu, H.; Identification of active sites for acidic oxygen reduction on carbon catalysts with and without nitrogen doping. Nat Catal. 2019, 2, 688-695.

68. Kim, C.K.; Ji, J.M.; Zhou, H.; Lu, C.; Kim, H.K.; Tellurium-Doped, Mesoporous Carbon Nanomaterials as Transparent Metal-Free Counter Electrodes for High-Performance Bifacial Dye-Sensitized Solar Cells. Nanomaterials, 2020, 10, 29.

69. Zong, L.; Wu, W.C.; Liu, S.; Yin, H.; Chen, Y.; Liu, C.; Fan, K.; Zhao, X.; Chen, X.; Wang, F.; Yang, Y.; Wang, L.; Feng. S.; Metal-free, active nitrogen-enriched, efficient bifunctional oxygen electrocatalyst for ultrastable zinc-air batteries. Energy Storage Materials, 27, 2020, 514-521.

70. Liang, S.; Liu, F.; Jiang, L.; Recent advances on nitrogen-doped metal-free materials for the selective catalytic oxidation of hydrogen sulfide. Current Opinion in Green and Sustainable Chemistry, 25, 2020, 100361. 
71. Saka, C.; Oxygen and nitrogen-doped metal-free microalgae carbon nanoparticles for efficient hydrogen production from sodium borohydride in methanol. International Journal of Hydrogen Energy, 46, 2021, 26298-26307.

72. Shui, J.; Wang, M.; Du, F.; Dai, L.; N-doped carbon nanomaterials are durable catalysts for oxygen reduction reaction in acidic fuel cells. Science Adv. 1, 2021, DOI: 10.1126/sciadv.1400129.

73. Xue, Y.; Liu, J.; Chen, H.; Wang, R.; Li, D.; Qu, J.; Dai, L.; Nitrogen-doped graphene foams as metal-free counter electrodes in high-performance dye-sensitized solar cells. Angew. Chem. Int. Ed. Engl. 51, 2012, 12124-12127.

74. Choi, H.C.; Park, J.; Kim, B.; Distribution and structure of $\mathrm{N}$ atoms in multiwalled carbon nanotubes using variable-energy X-ray photoelectron spectroscopy. J. Phys. Chem. B $2005,109,4333-4340$.

75. Hu, J.T.; Yang, P.D.; Lieber, C.M.; Nitrogen-driven $\mathrm{sp}(3)$ to $\mathrm{sp}(2)$ transformation in carbon nitride materials. Phys. Rev. B 1998, 57, R3185-R3188.

76. Ayala, P.; Arenal, R.; Rummeli, M.; Rubio, A.; Pichler, T., The doping of carbon nanotubes with nitrogen and their potential applications. Carbon 2010, 48, 575-586. 
77. Yang, J.B.; Liu, D.J.; Kariuki, N.N.; Chen, L.X.; Aligned carbon nanotubes with builtin FeN4 active sites for electrocatalytic reduction of oxygen. Chem. Commun. 2008, 3, 329331.

78. Lee, D.H.; Lee, W.J.; Kim, S.O.; Highly efficient vertical growth of wall-numberselected, N-doped carbon nanotube arrays. Nano Lett. 2009, 9, 1427-1432.

79. Ramanathan, T.; Fisher, F.T.; Ruoff, R.S.; Brinson, L.C.; Amino functionalized carbon nanotubes for binding to polymers and biological systems. Chem. Mater. 2005, 17, 1290-1295.

80. Li, J.; Vergne, M.J.; Mowles, E.D.; Zhong, W.H.; Hercules, D.M.; Lukehart, C.M.; Surface functionalization and characterization of graphitic carbon nanofibers (GCNFs). Carbon $2005,43,2883-2893$.

81. Tang, C.C.; Bando, Y.; Golberg, D.; Xu, F.F.; Structure and nitrogen incorporation of carbon nanotubes synthesized by catalytic pyrolysis of dimethylformamide. Carbon 2004, 42, $2625-2633$.

82. Stephan, O.; Ajayan P.M.; Colliex, C.; Redlich,P.; Lambert, J.M.; Bernier, P.; Lefin, P.; Doping graphitic and carbon nanotube structures with boron and nitrogen. Science 1994, $266,1683-1685$.

83. Droppa, R.; Hammer, P.; Carvalho, A.C.M.; dos Santos, M.C.; Alvarez, F.; Incorporation of nitrogen in carbon nanotubes. J. Non-Cryst. Solids 2002, 299, 874-879.

84. Hu, J.T.; Yang, P.D.; Lieber, C.M.; Nitrogen driven structural transformation in carbon nitride materials. Appl. Surf. Sci. 1998, 127, 569-573.

85. Rodil, S.E.; Milne, W.I.; Robertson, J.; Brown, L.M.; Maximized sp(3) bonding in carbon nitride phases. Appl. Phys. Lett. 2000, 77, 1458-1460. 
86. Yu, D.S.; Zhang, Q.; Dai, L.M.; Highly efficient metal-free growth of nitrogen-doped single-walled carbon nanotubes on plasma etched substrates for oxygen reduction. J. Am. Chem. Soc. 2010, 132, 15127-15129.

87. Luais, E.; Thobie-Gautier, C.; Tailleur, A.; Djouadi, M.A.; Granier, A.; Tessier, P.Y.; Debarnot, D.; Poncin-Epaillard, F.; Boujtita, M.; Preparation and modification of carbon nanotubes electrodes by cold plasmas processes toward the preparation of amperometric biosensors. Electrochim. Acta 2010, 55, 7916-7922.

88. Iijima, S.; Helical microtubules of graphitic carbon. Nature 1991, 354, 56-58.

89. Majeed, S.; Zhao, J.; Zhang, L.; Anjum, S.; Lie, Z.; Xu, G.; Synthesis and electrochemical applications of nitrogen-doped carbon nanomaterials, Nanotech. Rev. 2013, 2, $615-635$.

90. Czerw, R.; Terrones, M.; Charlier, J.C.; Blasé, X.; Foley, B.; Kamalakaran, R.; Grobert, N.; Terrones, H.; Tekleab, D.; Ajayan, P.M.; Blau, W., Ruhle, M.; Carroll, D.L.; Identification of electron donor states in N-doped carbon nanotubes. Nano Lett. 2001, 1, 457-460.

91. Terrones, M.; Grobert, N.; Terrones, H.; Synthetic routes to nanoscale BxCyNz architectures. Carbon 2002, 40, 1665-1684.

92. Christopher, P.W.; Glerup, M.; Nitrogen Doping in Carbon Nanotubes. Journal of Nanoscience and Nanotechnology, 2005, 5, 1345-1363.

93. Villalpando-Paez, F.; Romero, A.H.; Munoz-Sandoval, E.; Martinez, L.M.; Terrones, H.; Terrones, M.; Fabrication of vapor and gas sensors using films of aligned CNx nanotubes. Chem. Phys. Lett. 2004, 386, 137-143. 
94. Doytcheva, M.; Kaiser, M.; Verheijen, M.A.; Reyes-Reyes M.; Terrones, M.; de Jonge N.; Electron emission from individual nitrogen-doped multi-walled carbon nanotubes. Chem. Phys. Lett. 2004, 396, 126-130.

95. Zhang, J.J.; Cheng, F.F.; Zheng, T.T.; Zhu, J.J.; Design and implementation of electrochemical cytosensor for evaluation of cell surface carbohydrate and glycoprotein. Anal. Chem. 2010, 82, 3547-3555.

96. Souza, A.M.; Rocha, A.R.; Fazzio, A.; da Silva, A.J.R.; Ab-initio calculations for a realistic sensor: a study of CO sensors based on nitrogen-rich carbon nanotubes. AIP Adv. $2012,2,1-8$.

97. Terrones, M.; Kamalakaran, R.; Seeger, T.; Ruhle, M.; Novel nanoscale gas containers: encapsulation of N-2 in CNx nanotubes. Chem. Commun. 2000, 23, 2335-2336.

98. Peng, Q.Y.; He, X.D.; Li, Y.B.; Wang, C.; Wang, R.G.; Hu, P.A.; Yan, Y.D.; Sritharan, T.; Chemically and uniformly grafting carbon nanotubes onto carbon fibers by poly(amidoamine) for enhancing interfacial strength in carbon fiber composites. J. Mater. Chem. 2012, 22, 5928-5931.

99. Jiang, K.Y.; Eitan, A.; Schadler, L.S.; Ajayan, P.M.; Siegel, R.W.; Grobert, N.; Mayne, M.; Reyes-Reyes M.; Terrones, H.; Terrones, M.; Selective attachment of gold nanoparticles to nitrogen-doped carbon nanotubes. Nano Lett. 2003, 3, 275-277.

100. Kim, K.K.; Kim, D.; Kim, S.K.; Park, S.M.; Song, J.K.; Formation of ZnO nanoparticles by laser ablation in neat water. Chem. Phys. Lett. 2011, 511, 116-120.

101. Iijima S, Ichihashi T. Single-shell carbon nanotubes of 1-Nm diameter. Nature 1993, $363,603-605$. 
102. Takenobu, T.; Takano, T.; Shiraishi, M.; Murakami, Y.; Ata, M.; Kataura, H.; Achiba, Y.; Iwasa, Y., Stable and controlled amphoteric doping by encapsulation of organic molecules inside carbon nanotubes. Nat. Mater. 2003, 2, 683-688.

103. Terrones, M.; Carbon nanotubes: synthesis and properties, electronic devices and other emerging applications. Int. Mater. Rev. 2004, 49, 325-377.

104. Dai, L. M.; Griesser, H.J.; Mau, A.W.H.; Surface Modification by Plasma Etching and Plasma Patterning. J. Phys. Chem. B 1997, 101, 9548-9554.

105. Chen, Z.; Higgins, D.; Chen, Z.; Electrocatalytic activity of nitrogen doped carbon nanotubes with different morphologies for oxygen reduction reaction. Electrochimica Acta 2010, 55, 4799-4804.

106. Nxumalo, E.; Nyamori, V.; Coville, N.; CVD synthesis of nitrogen doped carbon nanotubes using ferrocene/aniline mixtures. Journal of Organometallic Chemistry 2008, 693, 2942-2948

107. Yang, Z.; Xia, Y.; Mokaya, R.; Aligned N-Doped Carbon Nanotube Bundles Prepared via CVD Using Zeolite Substrates. Chem. Mater. 2005, 17, 4502-4508.

108. He, M.; Zhou, S.; Zhang, J.; Liu, Z.; Robinson, C.; CVD Growth of N-Doped Carbon Nanotubes on Silicon Substrates and Its Mechanism. J. Phys. Chem. B 2005, 109, 9275-9279.

109. Kim, S.Y.; Lee, J.; Woong, C.; Park, J.; Seo, K.; Kim, B.; N-doped double-walled carbon nanotubes synthesized by chemical vapor deposition. Chemical Physics Letters, 2005, 413, 300-305.

110. Li, H.F.; Wu, F.; Wang, C.; Zhang, P.X.; Hu, H.Y.; Xie, N.; Pan, M.; Zeng, Z.; Deng, S.; Wu, M.H.; Vindogopal, K.; Dai, G.P.; One-Step Chemical Vapor Deposition Synthesis of 
3D N-doped Carbon Nanotube/N-doped Graphene Hybrid Material on Nickel Foam. Nanomaterials 2018, 8, 700.

111. Maslana, K.; Kalenczuk, R.; Zielinska, B.; Mijowska, E.; Synthesis and Characterization of Nitrogen-doped Carbon Nanotubes Derived from g-C3N4. Materials 2020, $13,1349$.

112. Xu, Z.W.; Li, H.J.; Fu, M.S.; Lu, H.J.; Sun, H.H.; Zhang, L.J.; Li, K.Z.; Wei, B.Q.; Lu, J.H.; Zhao, X.N.; Nitrogen-doped carbon nanotubes synthesized by pyrolysis of nitrogen-rich metal phthalocyanine derivatives for oxygen reduction. J. Mater. Chem. 2012, 22, 1823018236.

113. Gulino, G.; Vieira, R.; Amadou, J.; Nguyen, P; Ledoux, M.J.; Galvagno, S.; Centi, G.; Cuong, P.H.; synthesis of carbon nanotubes by chemical vapour deposition. Appl. Catal. A Gen. 2005, 279, 89-97.

114. Dong, J.P.; Qu, X.M.; Wang, L.J.; Zhao, C.J.; Xu, J.Q.; Electrochemistry of nitrogendoped carbon nanotubes $(\mathrm{CNx})$ with different nitrogen content and its application in simultaneous determination of dihydroxybenzene isomers. Electroanalysis 2008, 20, 19811986.

115. Liu, H.; Zhang, Y.; Li, R.Y.; Sun, X.L.; Desilets, S.; Abou-Rachid, H.; Jaidann, M.; Lussier, L.S.; Structural and morphological control of aligned nitrogen-doped carbon nanotubes. Carbon 2010, 48, 1498-1507.

116. Wang, Z.J.; Jia, R.R.; Zheng, J.F.; Zhao, J.G.; Li, L.; Song, J.L.; Zhu, Z.P.; Nitrogenpromoted self-assembly of $\mathrm{N}$-doped carbon nanotubes and their intrinsic catalysis for oxygen reduction in fuel cells. ACS Nano 2011, 5, 1677-1684. 
117. Xu, E.Y.; Wei, J.Q.; Wang, K.L.; Li, Z.; Gui, X.C.; Jia, Y.; Zhu, H.W.; Wu, D.H.; Doped carbon nanotube array with a gradient of nitrogen concentration. Carbon 2010, 48, $3097-3102$.

118. Abuilaiwi, F.A.; Laoui, T.; Al-Harthi, M.; Atieh, M.A.; Modification and functionalization of multiwalled carbon nanotube (MWCNT) via Fischer esterification. Arab. J. Sci. Eng. 2010, 35, 37-48.

119. Jiang, K.Y.; Schadler, L.S.; Siegel, R.W.; Zhang, X.J.; Zhang, H.F.; Terrones M. Protein immobilization on carbon nanotubes via a two-step process of diimide-activated amidation. J. Mater. Chem. 2004, 14, 37-39.

120. Ambrogi, V.; Gentile, G.; Ducati, C.; Oliva, M.C.; Carfagna, C.; Multiwalled carbon nanotubes functionalized with maleated poly(propylene) by a dry mechano-chemical process. Polymer 2012, 53, 291-299.

121. Chen, L.F.; Xie, H.Q.; Li, Y.; Yu, A.; Surface chemical modification of multiwalled carbon nanotubes by a wet-mechanochemical reaction. J. Nanomater. 2008, 783981, 1-5.

122. Fechler, N.; Fellinger, T.P.; Antonietti, M.; Template-free one-pot synthesis of porous binary and ternary metal nitride@N-doped carbon composites from ionic liquids. Chem. Mater. 2012, 24, 713-719.

123. Pan, C.T.; Qiu, L.H.; Peng, Y.J.; Yan, F.; Facile synthesis of nitrogen doped carbon-Pt nanoparticle hybrids via carbonization of poly $([\mathrm{Bvim}][\mathrm{Br}]-\mathrm{co}-\mathrm{acrylonitrile})$ for electrocatalytic oxidation of methanol. J. Mater. Chem. 2012, 22, 13578-13584.

124. Fan, L.S.; Chen, J.; Zhu, S.Y.; Wang, M.; Xu, G.B.; Determination of Cd2+ and Pb2+ on glassy carbon electrode modified by electrochemical reduction of aromatic diazonium salts. Electrochem. Commun. 2009, 11, 1823-1825. 
125. Wu, H.X.; Tong, R.; Qiu, X.Q.; Yang, H.F.; Lin, Y.H.; Cai, R.F.; Qian, S.X.; Functionalization of multiwalled carbon nanotubes with polystyrene under atom transfer radical polymerization conditions. Carbon 2007, 45, 152-159.

126. Maiyalagan, T.; Synthesis and electro-catalytic activity of methanol oxidation on nitrogen containing carbon nanotubes supported Pt electrodes. Appl. Catal. B Environ. 2008, 80, 286-295.

127. Wei, W.; Li, P.P.; Li, Y.; Cao, X.D.; Liu, S.Q.; Nitrogen-doped carbon nanotubes enhanced laccase enzymatic reactivity towards oxygen reduction and its application in biofuel cell. Electrochem. Commun. 2012, 22, 181-184.

128. Kooi, S.E.; Schlecht, U.; Burghard, M.; Kern, K.; Electrochemical modification of single carbon nanotubes. Angew. Chem. Int. Edit. 2002, 41, 1353-1355.

129. Tu, W.W.; Lei, J.P.; Jian, G.Q.; Hu, Z.; Ju, H.X.; Noncovalent assembly of picket-fence porphyrins on nitrogen-doped carbon nanotubes for highly efficient catalysis and biosensing. Chem.-Eur. J. 2010, 16, 4120-4126.

130. Zhu, J.; Zhou, H.; Zhang, C.; Jian, Z.; Mu, S.; Dual active nitrogen doped hierarchical porous hollow carbon nanospheres as an oxygen reduction electrocatalyst for zinc-air batteries. Nanoscale, 2017, 9, 13257-13263.

131. Gu, D.; Ma, R.; Zhou, Y.; Wang, F.; Yan, K.; Liu, Q.; Wang, J.; Synthesis of NitrogenDoped Porous Carbon Spheres with Improved Porosity toward the Electrocatalytic Oxygen Reduction. ACS Sustainable Chem. Eng. 2017, 5, 11, 11105-11116.

132. Zhang, H.; Chen, J.; Li, Y.; Liu, P.; Wang, Y.; An, T.; Zhao, H.; Nitrogen-Doped Carbon Nanodots@Nanospheres as An Efficient Electrocatalyst for Oxygen Reduction Reaction. Electrochimica Acta 165, 2015, 7-13. 
133. Wu, L.; Shen, Y.; Yu, L.; Xi, J.; Qiu, X.; Boosting vanadium flow battery performance by Nitrogen-doped carbon nanospheres electrocatalyst. Nano Energy 2016, 28, 19-28.

134. Wang, M.; Peng, F.; Wang, M.; Han, J.; N-Doped carbon nanospheres with nanocavities to encapsulate manganese oxides as ORR electrocatalysts. New J. Chem., 2020, 44, 14915-14921.

135. Wu, X.; Niu, Y.; Feng, B.; Yu, Y.; Huang, X.; Zhong, C.; Hu, W.; Li, C.M.; Mesoporous Hollow Nitrogen-Doped Carbon Nanospheres with Embedded MnFe2O4/Fe Hybrid Nanoparticles as Efficient Bifunctional Oxygen Electrocatalysts in Alkaline Media. ACS Appl. Mater. Interfaces 2018, 10, 24, 20440-20447.

136. Zhang, K.; Zhang, L.; Chen, X.; He, X.; Wang, X.; Dong, S.; Gu, L.; Liu, Z.; Huang, C.; Cui, G.; Molybdenum Nitride/N-Doped Carbon Nanospheres for Lithium-O2 Battery Cathode Electrocatalyst. ACS Appl. Mater. Interfaces 2013, 5, 9, 3677-3682.

137. Chen, Y.; Li, Z.; Zhu, Y.; Sun, D.; Liu, X.; Xu, L.; Tang, Y.; Atomic Fe Dispersed on N-Doped Carbon Hollow Nanospheres for High-Efficiency Electrocatalytic Oxygen Reduction. 31, 2018, 1806312.

138. Feng, Q.; Xiong, Y.; Xie, L.; Zhang, Z.; Lu, X.; Wang, Y.; Yuan, X.; Fan, J.; Li, H.; Wang, H.; Tungsten Carbide Encapsulated in Grape-Like N-Doped Carbon Nanospheres: OneStep Facile Synthesis for Low-Cost and Highly Active Electrocatalysts in Proton Exchange Membrane Water Electrolyzers. ACS Appl. Mater. Interfaces 2019, 11, 25123-25132.

139. Zhu, J.; Abdelkader, A.; Demko, D.; Deng, L.; Zhang, P.; He, T.; Wang, Y.; Huang, L.; Electrocatalytic Assisted Performance Enhancement for the Na-S Battery in Nitrogen-Doped Carbon Nanospheres Loaded with Fe. Molecules 2020, 25, 1585. 
140. Chi, J.Q.; Gao, W.K.; Zhang, L.M.; Dong, B.; Yan, K.L.; Lin, J.H.; Liu, B.; Chai, Y.M.; Liu, C.G.; Induced Phosphorization-Derived Well-Dispersed Molybdenum Phosphide Nanoparticles Encapsulated in Hollow N-Doped Carbon Nanospheres for Efficient Hydrogen Evolution. ACS Sustainable Chem. Eng. 2018, 6, 6, 7676-7686.

141. Gavrilov, N.; Pasti, I.A.; Vujkovic, M.; Travas-Sejdic, J.; Ciric-Marjanovic, G.; Mentus, S.V.; High-performance charge storage by N-containing nanostructured carbon derived from polyaniline. Carbon 2012, 50, 3915-3927.

142. Geim, A.K.; Novoselov, K.S.; The rise of graphene. Nat. Mater. 2007, 6, 183-191.

143. Hass, J.; de Heer, W.A.; Conrad, E.H.; The growth and morphology of epitaxial multilayer graphene. J. Phys.-Condens. Mater. 2008, 20, 323202.

144. Wang, C.D.; Zhou, Y.A.; He, L.F.; Ng, T.W.; Hong, G.; Wu, Q.H.; Gao, F.; Lee, C.S.; Zhang, W.J.; In situ nitrogen-doped graphene grown from polydimethylsiloxane by plasma enhanced chemicalvapor deposition. Nanoscale 2013, 5, 600-605.

145. Gao, Y.J.; Hu, G.; Zhong, J.; Shi, Z.J.; Zhu, Y.S.; Su, D.S.; Wang, J.G.; Bao, X.H.; Ma, D.; Nitrogen-doped sp2-hybridized carbon as a superior catalyst for selective oxidation. Angew. Chem. Int. Edit. 2013, 52, 2109-2113.

146. Jeong, H.M.; Lee, S.Y.; Shin, W.H.; Kwon, J.H.; Shakoor, A.; Hwang, T.H.; Kim, S.Y.; Kong, B.S.; Seo, J.S.; Lee, Y.M.; Kang, J.K.; Choi, J.W.; Silicon@ porous nitrogen-doped carbon spheres through a bottom-up approach are highly robust lithium-ion battery anodes. RSC. Adv. 2012, 2, 4311-4317.

147. Li, Y.; Zhao, Y.; Cheng, H.H.; Hu, Y.; Shi, G.Q.; Dai, L.M.; Qu, L.T.; Nitrogendoped graphene quantum dots with oxygen-rich functional groups. J. Am. Chem. Soc. 2012, 134, 1518. 
148. Jeong, H.M.; Lee, J.W.; Shin, W.H.; Choi, Y.J.; Shin, H.J.; Kang, J.K.; Choi, J.W.; Nitrogen-doped graphene for high-performance ultracapacitors and the importance of nitrogendoped sites at basal planes. Nano Lett. 2011, 11, 2472-2477.

149. Jin, Z.; Yao, J.; Kittrell, C.; Tour, J.M.; Large-scale growth and characterizations of nitrogen-doped monolayer graphene sheets. ACS Nano 2011, 5, 4112-4117.

150. Wei, D.C.; Liu, Y.Q.; Wang, Y.; Zhang, H.L.; Huang, L.P.; Yu, G.; Synthesis of Ndoped graphene by chemical vapor deposition and its electrical properties. Nano Lett. 2009, 9, $1752-1758$.

151. Wang, Y.; Shao, Y.Y.; Matson, D.W.; Li, J.H.; Lin, Y.H.; Nitrogen-doped graphene and its application in electrochemical biosensing. ACS Nano 2010, 4, 1790-1798.

152. Zhang, C.H.; Fu, L.; Liu, N.; Liu, M.H.; Wang, Y.Y.; Liu, Z.F.; Synthesis of nitrogendoped graphene using embedded carbon and nitrogen sources. Adv. Mater. 2011, 23, 10201024.

153. Li, X.L.; Wang, H.L.; Robinson, J.T.; Sanchez, H.; Diankov, G.; Dai, H.J.; Simultaneous nitrogen doping and reduction of graphene oxide. J. Am. Chem. Soc. 2009, 131, $15939-15944$.

154. Sheng, Z.H.; Shao, L.; Chen, J.J.; Bao, W.J.; Wang, F.B.; Xia, X.H.; Catalyst free synthesis of nitrogen-doped graphene via thermal annealing graphite oxide with melamine and its excellent electrocatalysis. ACS Nano 2011, 5, 4350-4358.

155. Yang, S.Y.; Chang, K.H.; Huang, Y.L.; Lee, Y.F.; Tien, H.W.; Li, S.M.; Lee, Y.H.; Liu, C.H.; Ma, C.C.M.; Hu, C.C.; A powerful approach to fabricate nitrogen-doped graphene sheets with high specific surface area. Electrochem. Commun. 2012, 14, 39-42. 
156. Mayavan, S.; Sim, J.B.; Choi, S.M.; Easy synthesis of nitrogen doped graphene-silver nanoparticle hybrids by thermal treatment of graphite oxide with glycine and silver nitrate. Carbon 2012, 50, 5148-5155.

157. Qu, L.T.; Liu, Y.; Baek, J.B.; Dai, L.M.; Nitrogen-doped graphene as efficient metalfree electrocatalyst for oxygen reduction in fuel cells. ACS Nano 2010, 4, 1321-1326.

158. Panchokarla, L.S.; Subrahmanyam, K.S.; Saha, S.K.; Govindaraj, A.; Krishnamurthy, H.R.; Waghmare, U.V.; Rao, C.N.R.; Synthesis, structure, and properties of boron- and nitrogen-doped graphene. Adv. Mater. 2009, 21, 4726-4730.

159. Hulicova, D.; Yamashita, J.; Soneda, Y.; Hatori, H.; Kodama, M.; Supercapacitors prepared from melamine-based carbon. Chem. Mater. 2005, 17, 1241-1247.

160. Yang, H.B.; Miao, J.; Hung, S.F.; Chen, J.; Tao, H.B.; Wang, X.; Zhang, L.; Chen, R.; Gao, J.; Chen, H.M.; Dai, L., Liu, B.; Identification of catalytic sites for oxygen reduction and oxygen evolution in N-doped graphene materials: Development of highly efficient metal-free bifunctional electrocatalyst. Science Adv. 2016, 2, DOI: 10.1126/sciadv.1501122.

161. Liu, Y.; Zhao, J.; Cai, Q.; Pyrrolic-nitrogen doped graphene: a metal-free electrocatalyst with high efficiency and selectivity for the reduction of carbon dioxide to formic acid: a computational study. Phys. Chem. Chem. Phys., 2016,18, 5491-5498.

162. Ju, M.J.; Kim, J.C.; Choi, H.J.; Choi, I.T.; Sang, G.K.; Lim, K.; Ko, J.; Lee, J.J.; Jeon, I.Y.; Baek, J.B.; Kim, H.K.; N-Doped Graphene Nanoplatelets as Superior Metal-Free Counter Electrodes for Organic Dye-Sensitized Solar Cells. ACS Nano 2013, 7, 6, 5243-5250.

163. Rahsepar, M.; Nobakht, M.R.; Kim, H.; Pakshir, M.; Facile enhancement of the active catalytic sites of $\mathrm{N}$-doped graphene as a high-performance metal-free electrocatalyst for oxygen reduction reaction. Applied Surface Science, 447, 2018, 182-190. 
164. Maouche, C.; Zhou, Y.; Li, B.; Cheng, C.; Wu, Y.; Li, J.; Gao, S.; Yang, J.; Thermal treated three-dimensional $\mathrm{N}$-doped graphene as efficient metal free-catalyst for oxygen reduction reaction. Journal of Electroanalytical Chemistry 2019, 853, 113536.

165. Kumar, M.P.; Raju, M.M.; Arunchander, A.; Selvaraj, S.; Kalita, G.; Narayanan, T.N.; Sahu, A.K.; Pattanayak, D.K.; Nitrogen Doped Graphene as Metal Free Electrocatalyst for Efficient Oxygen Reduction Reaction in Alkaline Media and Its Application in Anion Exchange Membrane Fuel Cells. Journal of The Electrochemical Society 2016, 163, F848.

166. Yang, D.S.; Bhattacharjya, D.; Inamdar, S.; Park, J.; Yu, J.S.; Phosphorus-Doped Ordered Mesoporous Carbons with Different Lengths as Efficient Metal-Free Electrocatalysts for Oxygen Reduction Reaction in Alkaline Media, J. Am. Chem. Soc. 2012, 134, 16127.

167. Yang, Z.; Yao, Z.; Li, G.; Fang, G.; Nie, H.; Liu, Z.; Zhou, X.; Chen, X.; Huang, S.; Sulfur- doped graphene as an efficient metal-free cathode catalyst for oxygen reduction, ACS Nano 2012, 6, 205.

168. Zhao, Y.; Yang, L.; Chen, S.; Wang, X.; Ma, Y.; Wu, Q.; Jiang, Y.; Qian, W.; Hu, Z.; Can boron and nitrogen co-doping improve oxygen reduction reaction activity of carbon nanotubes? J. Am. Chem. Soc. 2013, 135, 1201.

169. Sun, X.; Song, P.; Zhang, Y.; Liu, C.; Xu, W.; Xing, W.; A class of high performance metal-free oxygen reduction electrocatalysts based on cheap carbon blacks, Sci. Rep. 2013, 3, 2505.

170. Liu, Z.; Nie, H.; Yang, Z.; Zhang, J.; Jin, Z.; Lu, Y.; Xiao, Z.; Huang, S.; Sulfurnitrogen codoped three-dimensional carbon foams with hierarchical pore structures as efficient metal-free electrocatalysts for oxygen reduction reactions, Nanoscale 2013, 5, 3283. 
171. Li, Y.; Zhang, H.; Wang, Y.; Liu, P.; Yang, H.; Yao, X.; Wang, D.; Tang, Z.; Zhao, H.; A selfsponsored doping approach for controllable synthesis of $\mathrm{S}$ and $\mathrm{N}$ co-doped trimodalporous structured graphitic carbon electrocatalysts, Energy Environ. Sci. 2014, 7, 3720.

172. Liang, J.; Jiao, Y.; Jaroniec, M.; Qiao, S.Z.; Sulfur and nitrogen dual-doped mesoporous graphene electrocatalyst for oxygen reduction with synergistically enhanced performance, Angew. Chem. 2012, 51, 11496.

173. Wohlgemuth, S.A.; White, R.J.; Willinger, M.G; Titiricia, M.M.; Antoniettia, M.; A one-pot hydrothermal synthesis of sulfur and nitrogen doped carbon aerogels with enhanced electrocatalytic activity in the oxygen reduction reaction. Green Chem., 2012, 14, 1515.

174. Wohlgemuth, S.A.; Vilela, F.; Titirici, M.M.; Antonietti, M.; A one-pot hydrothermal synthesis of tunable dual heteroatom-doped carbon microspheres. Green Chem., 2012, 14, 741.

175. Wu, Y.P.; Fang, S.; Jiang, Y.; Holze, R.; Effects of doped sulfur on electrochemical performance of carbon anode. Journal of Power Sources. 2002, 108, 245 - 249.

176. Choi, C.H.; Park, S.H.; Woo, S.I.; Heteroatom doped carbons prepared by the pyrolysis of bio-derived amino acids as highly active catalysts for oxygen electro-reduction reactions. Green Chem., 2011,13, 406-412.

177. Inamdar, S.; Haram, S.; Synthesis and Characterization of Uncapped $\gamma$-Fe2O3 Nanoparticles Prepared by Flame Pyrolysis of Ferrocene in Ethanol. Journal of Nanoscience and Nanotechnology 2006, 6, 2155.

178. Inamdar, S.; Choi, H.S.; Wang, P.; Song, M.Y.; Yu, J.S.; Sulfur-containing carbon by flame synthesis as efficient metal-free electrocatalyst for oxygen reduction reaction. Electrochemistry Communications 2013, 30, 9-12. 
179. Park, J.; Jang, Y.J.; Kim, Y.J.; Song, M.S.; Yoon, S.; Kim, D.H.; Kim, S.J.; Sulfurdoped graphene as a potential alternative metal-free electrocatalyst and Pt-catalyst supporting material for oxygen reduction reaction. Phys. Chem. Chem. Phys., 2014, 16, 103-109.

180. Zhang, H.; Niu, Y.; Hu, W.; Nitrogen/sulfur-doping of graphene with cysteine as a heteroatom source for oxygen reduction electrocatalysis. J Colloid Interface Sci 2017, 505, 3237.

181. Zhao, H.; Zhu, Y.P.; Ge, L.; Yuan, Z.Y.; Nitrogen and sulfur co-doped mesoporous hollow carbon microspheres for highly efficient oxygen reduction electrocatalysts. Int $\mathbf{J}$ Hydrogen Energy 2017, 42, 19010-19018.

182. Wang, Y.; Zhu, M.; Li, Y.; Zhang, M.; Xue, X.; Shi, Y.; Heteroatom-doped porous carbon from methyl orange dye wastewater for oxygen reduction. Green Energy Environ 2018, $3,172-178$

183. Tumwesigye, K.S.; Oliveira, J.C.; Sousa-Gallagher, M.J.; New sustainable approach to reduce cassava borne environmental waste and develop biodegradable materials for food packaging applications. Food Package Shelf Life 2016, 7, 8-19.

184. Mena-Duran, C.J.; Alonso-Lemus, I.L.; Quintana, P.; Barbosa, R.; Ordonez, L.C.; Escobar, B.; Preparation of metal-free electrocatalysts from cassava residues for the oxygen reduction reaction: A sulfur functionalization approach, Int. J. Hydrogen Energy 2018, 43, $3172-3179$. 
